\title{
ENDING PROSTITUTION EXPLOITATION: HOW NEW YORK STATE CAN BETTER SUPPORT SURVIVORS OF THE SEX TRADE THROUGH LEGISLATIVE REFORM
}

\author{
JULIA RIGAL*
}

\section{INTRODUCTION}

Linda grew up in Queens, with her parents and brothers. ${ }^{1}$ When she was a teenager, she ran away from home with her boyfriend. ${ }^{2}$ A month later, he brought her to Manhattan and soon started prostituting her. ${ }^{3}$ While she was in prostitution, Linda was arrested many times; she had no credit or place of her own. ${ }^{4}$ She stayed in prostitution until she was twenty-eight years old. ${ }^{5}$

Linda Oluch's story is in no way exceptional. Melanie Thompson, who also survived the New York sex trade, asserts that the overwhelming majority of people in prostitution "are in it by force, fraud, or coercion, or lack of choice." Jessica Raven states that she

\footnotetext{
*J.D. 2021, Columbia Law School; Double licence 2017, Université Paris 1 Panthéon-Sorbonne. Many thanks to Professor Colleen F. Shanahan for her guidance and support and to the staff of the Columbia Journal of Gender and Law for their suggestions and edits. I am deeply grateful to the many survivors of the sex trade who have educated me and inspired me to write this Note. Finally, I would like to dedicate this Note to my late grandmother, Bette Rae Prouty.
}

${ }^{1}$ Anne K. Ream, The Truth Teller, Linda Oluch, World Without Exploitation, https://www.worldwithoutexploitation.org/survivor/linda-oluch [https://perma.cc/SJ2N-URXP].

${ }^{2} I d$.

${ }^{3} I d$.

${ }^{4} I d$.

${ }^{5} I d$.

${ }^{6}$ Sex, Lies, and Classifieds-Dialogue \#3, Women’s MARch GLoB. (May 11, 2018), https://medium.com/womens-march-global/womens-march-global-dialogues-2fda4c97efad [https://perma.cc/GX5Z-KALV]. 
was one of thousands of youth in New York City who traded sex for a place to sleep. ${ }^{7}$ Further, New York is the state with the fifth most human trafficking cases in the country, ${ }^{8}$ the majority of which involve sexual exploitation. ${ }^{9}$ Current New York law criminalizes ${ }^{10}$ people in prostitution, ${ }^{11}$ thereby exacerbating their exploitation. ${ }^{12}$ Many activist groups argue that the New York legislature should amend the Penal Law so that people in prostitution are no longer criminalized. ${ }^{13}$

On June 10, 2019, New York State legislators introduced the "Stop Violence in the Sex Trades Act" (hereinafter "Gottfried-Salazar bill"). ${ }^{14}$ Decrim NY, the coalition that

\footnotetext{
${ }^{7}$ Jessica Raven, Stop Criminalizing Sex Work, New York: Let Adults Make Their Own Choices, N.Y. DAILY NEws (June 10, 2019), https://www.nydailynews.com/opinion/ny-oped-legalize-sex-work-new-york20190610-o3ymum27a5fj7pavejfgmjufru-story.html [https://perma.cc/7C84-A3DR].

${ }^{8}$ Jordan Fenster, Sex Trafficking: New York State 5th in the Nation, LoHud (Dec. 20, 2017), https://www.lohud.com/story/news/local/2017/12/20/sex-trafficking-new-york-state-5th-nation/969122001/ [https://perma.cc/83DD-3JQY].

${ }^{9}$ See id.; U.N. Off. on Drugs \& Crime, Global Rep. on Trafficking in Persons 2018, at 30, U.N. Sales No. E.19.IV.2 (2018) (reporting that 71\% of trafficking victims detected in North America in 2016 were trafficked for sexual exploitation).

${ }^{10}$ See N.Y. Penal LaW $§ 230.00$ (McKinney 2019).

${ }^{11}$ This Note refers to people who are engaged in prostitution as "people in prostitution" or "prostituted people." This Note does not use the term "prostitute," as it carries negative connotations. This Note also does not use the term "sex worker," which has the effect of sanitizing the sex trade and hiding the sexual abuse that is inherent to the majority of prostitution. See Gabrielle Fonrouge, Survivors, Advocates Upset over Teen Vogue's 'Sex Work Is Real Work' Op-Ed, N.Y. Post (Apr. 30, 2019), https://nypost.com/2019/04/30/exprostitutes-upset-over-teen-vogues-sex-work-is-real-work-op-ed/ [https://perma.cc/64N4-LZMZ].
}

${ }^{12}$ See Catharine A. MacKinnon, Prostitution and Civil Rights, 1 Mich. J. Gender \& L. 13, 20, 25 (1993) (arguing that the state enforces the exploitation of prostituted women by making it harder for them to exit prostitution); Marian Hatcher et al., Exited Prostitution Survivor Policy Platform, Dignity: A J. ON SeXuAL EXPLOITATION \& VIOLENCE, Dec. 2018, art. 10, at 1, 2-3 (explaining the impact of criminalization for survivors).

${ }^{13}$ See Our Goals, DECRIM NY, https://www.decrimny.org [https://perma.cc/7V28-ZDWY] [hereinafter Our Goals, DeCRim NY]; Who We Are, New Yorkers FOR THE EQUALITY MODEL, https://www.equalitymodelny.org [https://perma.cc/5DYT-QH46].

${ }^{14}$ S. 6419, 2019-2020 Reg. Sess. (N.Y. 2019); New York State Bills for the 2019-2020 Legislative Session, DECRIM NY, https://www.decrimny.org/advocacy [https://perma.cc/7VBX-9XBT] (stating that the bill was drafted by sponsors Assembly Member Richard Gottfried and Senator Julia Salazar with Decrim NY). 
pushed for the bill, states that it aims to "decarcerate" the sex trade ${ }^{15}$ and to decriminalize "consenting adults who trade sex, collaborate with or support sex working peers, or patronize adult sex workers." 16 Sponsors of the bill also seek to reduce violence and abuse in the sex trade. ${ }^{17}$

In recent years, various countries chose to modify their legislative approach to prostitution with the objective of ending the abuse of people in prostitution. ${ }^{18}$ While some countries made the sex trade legal, others chose to decriminalize and support people in prostitution and to penalize prostitution buyers, ${ }^{19}$ pimps, ${ }^{20}$ and brothels. ${ }^{21}$

In the coming years, regardless of whether the Gottfried-Salazar bill is passed, many state legislatures will likely consider how they should update their prostitution laws. ${ }^{22}$ This Note aims to determine the best legislative approach for states to adopt. Specifically, this Note analyzes the likely effects of implementing the Gottfried-Salazar bill. The

15 Our Goals, DECRIM NY, supra note 13 (defining Decrim NY as a coalition of organizations that seeks "to Decriminalize, Decarcerate and Destigmatize the Sex Trades in New York City and State").

${ }^{16}$ For Immediate Release: Decrim NY, Legislators Intro First Statewide Bill to Decriminalize Sex Work, DECRIM NY (June 10, 2019), https://www.decrimny.org/post/for-immediate-release-decrim-ny-legislatorsintro-first-statewide-bill-to-decriminalize-sex-work [https://perma.cc/5LMD-XWPY] [hereinafter Press Release, DECRIM NY].

${ }^{17}$ See id. (quoting Senator Julia Salazar, Senator Jessica Ramos, and Assembly Member Richard Gottfried).

${ }^{18}$ See infra Section I.B.

19 There is no single commonly used term to refer to those who pay for sex. See Anita Bernstein, Working Sex Words, 24 Mich. J. GENDER \& L. 221, 225, 245-46. This Note uses the term "prostitution buyer" to recognize the fact that the person who pays for sex is as much a part of the transaction as the prostituted person. See id.

${ }^{20}$ Although some states such as California and Georgia have enacted felonies called "pimping," most state laws use terms such as "promoting" or "facilitating" prostitution. See Bernstein, supra note 19, at 249. To avoid resorting to euphemisms, this Note uses the term "pimping" to refer to the advancement or promotion of another's prostitution.

${ }^{21}$ See infra Section I.B.

${ }^{22}$ See, e.g., Erik Ortiz, New York State Lawmakers Introduce Bill to Decriminalize Sex Work, NBC NEWS (June 10, 2019), https://www.nbcnews.com/news/us-news/new-york-state-lawmakers-introduce-billdecriminalize-sex-work-n1015891 [https://perma.cc/47SA-6B72] (mentioning that decriminalization bills have been introduced in Massachusetts and Maine); D.C. BD. OF ElECTIONS, NotiCE OF PuBLIC HEARING (2020), https://www.dcboe.org/CMSPages/GetFile.aspx?guid=6e20aac8-36f7-4464-9096-2c17684fb1b9 [https://perma.cc/R2WU-5VE4] (announcing a public hearing to review a proposed measure seeking to fully decriminalize the sex trade in the District of Columbia). 
author shares the bill's overarching objective of improving the lives of people in prostitution and, therefore, agrees that they should not be criminalized. While most scholarship has focused either on making the sex trade legal, ${ }^{23}$ on penalizing pimps and prostitution buyers more harshly, ${ }^{24}$ or on creating services for people in prostitution, ${ }^{25}$ this Note argues for a legislative model that prioritizes the needs of survivors and addresses the root causes of the system of prostitution in order to dismantle it.

Part I explains the different legislative approaches to prostitution adopted in various countries in recent years and details the ways in which the Gottfried-Salazar bill seeks to amend New York's current prostitution laws. Part II analyzes whether the GottfriedSalazar bill will accomplish some of its stated goals based on the results of similar prostitution legislation adopted in other countries. Part III proposes an alternative solution to the Gottfried-Salazar bill based on the Equality Model and principles of transformative justice.

\section{Background on Legislative Approaches to Prostitution and the Gottfried-Salazar Bill}

This Part explores various theories of what prostitution is and the different legal approaches to the sex trade adopted by other countries, U.S. states, and the GottfriedSalazar bill. Section A explains the tenets of three theoretical conceptions of prostitution which have led to different legal frameworks. Section B details the legal regimes relating to prostitution that various countries have adopted in the twenty-first century, either by making the sex trade legal or by adopting the Equality Model. Section C provides background on prostitution law and policy in the United States and examines key provisions of the Gottfried-Salazar bill.

\footnotetext{
${ }^{23}$ See, e.g., Frankie Herrmann, Building a Fair and Just New York: Decriminalize Transactional Sex, 15 HASTINGS RACE \& PoverTy L. J. 65, 67-70 (2018) (arguing that New York should fully decriminalize the sex trade).

${ }^{24}$ See, e.g., Elizabeth M. Donovan, Same as It Ever Was: In Support of the Rights of Sex Trafficking Victims, 36 QUINNIPIAC L. REV. 489, 634 (2018) (encouraging Congress to increase penalties and law enforcement efforts against traffickers and prostitution buyers).

${ }^{25}$ See, e.g., Ane Mathieson et al., Prostitution Policy: Legalization, Decriminalization and the Nordic Model, 14 SEATTLE J. FOR Soc. Just. 367, 422 (2015) (advocating for increased survivor services in Seattle based on those provided in Sweden).
} 


\section{A. Theoretical Approaches to Prostitution Policy}

Scholars have identified three main theoretical views of prostitution, which have led to distinct policy approaches. ${ }^{26}$ These three theories can be categorized as the prostitution-as-sin position, the prostitution-as-work position, and the prostitution-asexploitation position. ${ }^{27}$

\section{Prostitution as Sin}

The prostitution-as-sin position maintains that prostitution is immoral and caused by the sinful nature of women. ${ }^{28}$ Proponents of this position advocate for the full criminalization of prostitution, which includes the criminalization of being paid for sex, of paying for sex, and of advancing or profiting from the prostitution of others. ${ }^{29}$ Under a full criminalization regime, prostitution is traditionally considered to be a "victimless crime. ${ }^{, 30}$ However, the overwhelming majority of people in prostitution are forced into it by another person, ${ }^{31}$ end up in the sex trade as a consequence of trauma, ${ }^{32}$ or sell their

\footnotetext{
${ }^{26}$ Id. at 368; see also Stephanie M. Berger, No End in Sight: Why the "End Demand" Movement Is the Wrong Focus for Efforts to Eliminate Human Trafficking, 35 HARV. J. L. \& GENDER 523, 528-29 (2012) (explaining that there are three main categories of legal frameworks to regulate the sex trade: complete criminalization, complete decriminalization (which can include some regulation), and partial decriminalization).

${ }^{27}$ Nicole Bingham, Nevada Sex Trade: A Gamble for the Workers, 10 YALE J.L. \& FeminiSM 69, 70 (1998); see also Catharine A. MacKinnon, Trafficking, Prostitution, and Inequality, 46 HARV. C.R.-C.L. L. REV. 271, 272-74 (2011); Mathieson et al., supra note 25, at 368-69.

${ }^{28}$ Herrmann, supra note 23, at 73-74; Mathieson et al., supra note 25, at 368-69.

${ }^{29}$ Herrmann, supra note 23 , at $73-75$.

${ }^{30}$ Mathieson et al., supra note 25, at 374.

${ }^{31}$ See Sex, Lies, and Classifieds-Dialogue \#3, supra note 6 (stating that " $98 \%$ of the people in prostitution are in it by force, fraud, or coercion, or lack of choice" and recounting the experience of Melanie Thompson, who was first trafficked when she was twelve years old).

${ }^{32}$ Max Waltman, Sweden's Prohibition of Purchase of Sex: The Law's Reasons, Impact, and Potential, 34(5) WOMEN's STUD. INT'L F. 449, 451 (2011) (stating that Swedish research on prostitution concluded that women and girls often enter prostitution a result of being neglected, sexually abused, and traumatized as children).
} 
bodies because it is their best means of survival. ${ }^{33}$ The majority of people who have been involved in prostitution report being sexually abused in their childhood. ${ }^{34}$ Studies have further shown that approximately $90 \%$ of people in prostitution wish to exit prostitution. ${ }^{35}$ Prohibitionist regimes therefore criminalize people who engage in prostitution due to trauma or economic need.

Further, the system of prostitution both emerges from and perpetuates various forms of structural oppression such as racism, sexism, and classism. ${ }^{36}$ It is estimated that at least $80 \%$ of the people who are prostituted throughout the world are female and most of them are between the ages of thirteen and twenty-five. ${ }^{37}$ The quasi-totality of prostitution buyers are men. ${ }^{38}$ Women of color and transgender women are vastly overrepresented in

\footnotetext{
${ }^{33}$ Berger, supra note 26, at 531 (stating that the "more voluntary" forms of prostitution often result from extreme poverty and a lack of other options); Raven, supra note 7 (stating that the author engaged in "survival sex" from the age of fifteen, and that almost $40 \%$ of Black trans people trade sex to survive).

${ }^{34}$ Waltman, supra note 32, at 451 (estimating the rate of childhood sexual abuse as $55 \%$ to $90 \%$ ).

${ }^{35}$ Elizabeth Fry Soc'y of Toronto, Streetwork Outreach With Adult Female Street Prostitutes 13 (1987); Melissa Farley et al., Prostitution and Trafficking in Nine Countries: An Update on Violence and Posttraumatic Stress Disorder, J. Trauma PraC., Jan. 2004, at 33, 34 (finding that, out of 854 people interviewed who were currently or recently in prostitution in nine countries, $89 \%$ wanted to escape prostitution).
}

${ }^{36}$ Cheryl Nelson Butler, A Critical Race Feminist Perspective on Prostitution \& Sex Trafficking in America, YALE J. L. \& FEMINISM 95 (2015) (arguing that structural racism, sexism, and class inequality coerce women of color into prostitution and "obscure their consent").

${ }^{37}$ Marie Lombard-Latune, 40 à 42 millions de personnes se prostituent dans le monde, FigARO (Jan. 13, 2012) (Fr.), https://www.lefigaro.fr/actualite-france/2012/01/13/01016-20120113ARTFIG00766-40-a-42millions-de-personnes-se-prostituent-dans-le-monde.php [https://perma.cc/7EL2-U2U8]; see also Rights4GiRls, Racial \& GENDER DisPaRities IN THE SEX TRADE (2017), https://rights4girls.org/wpcontent/uploads/r4g/2016/08/Racial-Disparities-Fact-Sheet-11.2017.pdf [https://perma.cc/R666-QK93] (stating that a two-year review of all suspected trafficking incidents across the United States found that 94\% of victims were female).

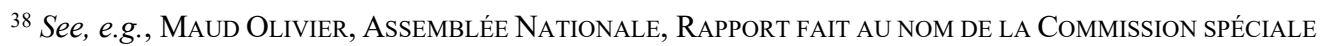
CHARGÉE D'EXAMINER LA PROPOSITION DE LOI ( $\left.{ }^{\circ} 1437\right)$, RENFORÇANT LA LUTTE CONTRE LE SYSTÈME PROSTITUTIONNEL 9 (2013) (Fr.) (finding that 99\% of prostitution buyers in France are men); Martin A. Monto, Female Prostitution, Customers, and Violence, Violence AgAinst Women, Feb. 2004, at 160, 165 (stating that the "overwhelming majority" of prostitution buyers in the United States are employed adult men). 
the sex trade ${ }^{39}$ and are more likely to get arrested on prostitution charges. ${ }^{40}$ Studies have shown that the majority of prostitution buyers are middle- to upper-class white men. ${ }^{41}$ Prostitution is therefore not only an issue of gender inequality, but also one of white supremacy and class-based injustice. Predominantly white, middle-class men with disposable income are able to demand sexual access to the most vulnerable members of society. Moreover, people in prostitution have historically been arrested and prosecuted

\footnotetext{
${ }^{39}$ A special report by the Bureau of Justice Statistics stated that $94 \%$ of sex trafficking victims were female, $40 \%$ were Black, and 24\% were Latinx. See Duren Banks \& Tracey Kyckelhahn, Bureau of Just. Stat., U.S. DeP'T OF Just., Characteristics OF SUSPECTED HUMAN TrafFicking INCIDENTS, 2008-2010, at 6 (2011). Black and Latinx people represented, respectively, $13 \%$ and $16 \%$ of the U.S. population the last year the study was conducted. U.S. Census BuREau, 2010 Census Shows America's Diversity (Mar. 24, 2011), https://www.census.gov/newsroom/releases/archives/2010_census/cb11-cn125.html [https://perma.cc/G2DTUL3D]. In South Dakota, approximately $40 \%$ of reported sex trafficking victims are Native women. Danielle Ferguson, Law Enforcement. Native Communities Focus on Sex Trafficking Prevention Training, ARGUS LEADER (Aug. 27, 2016), https://www.argusleader.com/story/news/crime/2016/08/27/law-enforcementnative-communities-focus-sex-trafficking-prevention-training/89273822/ [https://perma.cc/2TUJ-N7FN]. Only $9 \%$ of the population of South Dakota reported being Native. U.S. CENSUS BUREAU, QuickFacts: South Dakota, https://www.census.gov/quickfacts/SD [https://perma.cc/V59M-R7J3].According to the 2015 U.S. Transgender Survey, $12 \%$ of the 27,715 respondents had prostituted in exchange for money, $6 \%$ had done so in exchange for food, and $8 \%$ had done so for a place to sleep. SANDY E. JAMES ET AL., NAT'L CTR. FOR Transgenderl Equal., The Report Of THE 2015 U.S. TransGender SuRVEy 158 (2016). Higher rates of prostitution for money were recorded for transgender women of color, including Black (42\%), Native (28\%), multiracial (27\%), Latina (23\%), and Asian (22\%) women, compared to $11 \%$ for white women. Id. at 159 .
}

${ }^{40}$ In $2018,38.8 \%$ of adults and $37.7 \%$ of children arrested for prostitution or commercialized vice were Black or African American. Fed. Bureau of Investigation, U.S. DeP'T OF Just., ARreStS By RACE AND ETHNICITY, 2018 tbls.43C \& 43B, https://ucr.fbi.gov/crime-in-the-u.s/2018/crime-in-the-u.s.2018/tables/table-43 [https://perma.cc/HYH6-MGDJ]. Of all respondents to the 2015 U.S. Transgender Survey, $3 \%$ had interacted with police while participating in prostitution or when the police thought they were participating in it. JAMES ET AL., supra note 39, at 162 . Of these respondents, $32 \%$ reported being arrested during at least one interaction, with Black respondents more likely to report that the interaction with the police had led to an arrest (50\%). Id. at 163 .

${ }^{41}$ A 2012 study by Christine Milrod and Martin A. Monto found that out of 584 men who were paying members of TheEroticReview.com, 84.9\% of them were Caucasian, and their average income was \$141,510. Christine Milrod \& Martin A. Monto, The Hobbyist and the Girlfriend Experience: Behaviors and

Preferences of Male Customers of Internet Sexual Service Providers, Deviant BeHAVIOR, Nov. 2012, at 792, 799. In King County, Washington, $80 \%$ of prostitution buyers are white men. See also RigHTs4GiRLS, supra note 37, at 2 n. viii (citing Valiant Richey, Presenter, Ind. Emergency Nurses Assoc., Oral Presentation: Reducing Demand for the Commercial Sexual Exploitation of Minors in Your Community (May 30, 2017)). Monto, supra note 38, at 169 (finding that, based on various studies conducted in the United States, prostitution buyers "generally reflect the ethnicity of the cities and locales in which they live"). 
at vastly higher rates than prostitution buyers. ${ }^{42}$ This unequal enforcement of the law can be explained in part by a sexist double standard that vilifies women in prostitution as sexual deviants incapable of redemption and excuses men who buy prostitution as normal people attempting to satisfy their naturally irrepressible desires. ${ }^{43}$

Today, some scholars adopt a utilitarian defense of full criminalization arguing that it gives law enforcement more tools to intervene in the lives of prostituted people and protect them from exploiters. ${ }^{44}$ However, it does not make sense to criminalize people that the law seeks to protect from exploitation. ${ }^{45}$ Criminalization tends to make prostituted women wary of asking law enforcement for help, for fear of being arrested or victimized by the police. ${ }^{46}$ Moreover, forcing services on prostituted people runs the risk of further traumatizing them. ${ }^{47}$

\footnotetext{
${ }^{42}$ See Julie Lefler, Shining the Spotlight on Johns: Moving Toward Equal Treatment of Male Customers and Female Prostitutes, 10 Hastings Women's L.J. 11, 11 (1999); see also Monto, supra note 38, at 160 (finding that customers only constituted around $10 \%$ of prostitution-related arrests in the 1980s and 1990s); People v. Burton, 432 N.Y.S.2d 312, 314-15 (Buff. City Ct. 1980) (finding that around 90\% of the people arrested in Buffalo for prostitution-related offenses were female, like in the defendant's case); VILLANOVA UNIV. Charles Widger Sch. of L., Report on Commercial SeXual Exploitation in Pennsylvania 11 (2018), https://cseinstitute.org/wp-content/uploads/2018/05/2018-report-final-B-2.pdf [https://perma.cc/XW5ZMU6C] (finding that, in Pennsylvania, $76 \%$ of prostitution arrests are for selling and $24 \%$ are for buying).

${ }^{43}$ Lefler, supra note 42, at 14-15; Monto, supra note 38, at 163-64 (arguing that this conception of prostitution as inevitable to fulfill men's sexual needs ignores the fact that sexual desires are shaped by society and "reinforces a sense of masculine entitlement to sexual access that places others' needs as secondary").

${ }^{44}$ Brynn N.H. Jacobson, Comment, Addressing the Tension Between the Dual Identities of the American Prostitute: Criminal and Victim; How Problem-Solving Courts Can Help, 1037 Seattle U. L. Rev. 1023, 1035, 1051 (2019).

${ }^{45}$ See Waltman, supra note 32, at 454-55 (quoting the Swedish Parliament). Behavior is designated as a crime in order to allow the government to punish - not protect - the perpetrator. See Crime, MERRIAMWEBSTER, https://www.merriam-webster.com/dictionary/crime [https://perma.cc/QB4V-WLA8].

${ }^{46}$ See Heather Monasky, On Comprehensive Prostitution Reform: Criminalizing the Trafficker and the Trick, but Not the Victim—Sweden's Sexköpslagen in America, 37 WM. Mitchell L. ReV. 1989, 2038 (2011).

${ }^{47}$ See id.
} 


\section{Prostitution as Work}

Proponents of the prostitution-as-work position maintain that people should have the right to prostitute themselves. ${ }^{48}$ They prefer the term "sex work," do not consider sex work to be inherently harmful, and assert that there is a clear distinction between human trafficking, which is coercive, and consensual commercial sex, which is not. ${ }^{49}$ Understandings of prostitution as work range from the view that prostitution is a conscious choice to work in a high-risk profession to the position that it is a job like any other. $^{50}$

Generally, defenders of the prostitution-as-work position argue for the legalization or full decriminalization of the sex trade. ${ }^{51}$ Supporters of full decriminalization often purport that there is a clear distinction between legalization and decriminalization schemes. ${ }^{52}$

\footnotetext{
${ }^{48}$ See, e.g., Valerie Jenness, From Sex as Sin to Sex as Work: COYOTE and the Reorganization of Prostitution as a Social Problem, Soc. ProbS., Aug. 1990, at 403, 405-06 (citing various arguments claiming that most prostitution is voluntary and that women should have the right to sell sexual services); David A. J. Richards, Commercial Sex and the Rights of the Person: A Moral Argument for the Decriminalization of Prostitution, 127 U. PA. L. REV. 1195, 1276-78 (1979) (arguing that engaging in commercial sex is a human right and a feature of exercising bodily autonomy); see also Raven, supra note 7 (stating that, for those involved in the sex trade, decriminalization is an issue of bodily autonomy- "our bodies, our choice").

${ }^{49}$ See Understanding Sex Work in an Open Society, Open Soc’y Found., https://www.opensocietyfoundations.org/explainers/understanding-sex-work-open-society [https://perma.cc/F39Z-T2CU].

${ }^{50}$ Fed. Ministry for Fam. Aff., Senior Citizens, Women and Youth, Report by the Federal Government on the Impact of the Act Regulating the Legal Situation of Prostitutes (Prostitution ACt) 8 (2007) (Ger.) [hereinafter German Report on the IMPACt OF the Prostitution Act]; Monto, supra note 38 , at 163 .

51 See, e.g., German Report on the Impact of the Prostitution Act, supra note 50, at 8-9; Open Soc'y Found., supra note 49; Doreen Carvajal, Amnesty International Votes for Policy Calling for Decriminalization of Prostitution, N.Y. Times (Aug. 11, 2015), https://www.nytimes.com/2015/08/12/world/europe/amnesty-international-votes-for-policy-calling-fordecriminalization-of-prostitution.html [https://perma.cc/9PS6-ZHZF].

52 See, e.g., Rachel Marshall, Sex Workers and Human Rights: A Critical Analysis of Laws Regarding Sex Work, 23 WM. \& MARY J. WOMEN \& L. 47, 56 (2016) (distinguishing between four legal approaches to prostitution: prohibition, legalization, abolition, and decriminalization); see also Raven, supra note 7 (distinguishing the New York decriminalization bill from the legalization models in Nevada and Amsterdam). But see Mathieson et al., supra note 25, at 378-80 (arguing that legalization and decriminalization are similar in theory and in practice as decriminalization transfers regulation of the sex trade to local councils); infra
} 
They argue that, while legalization places the sex trade under state control through regulation, a decriminalization regime simply "removes all laws related to sex work." 53 They criticize regulation for requiring state resources, putting people at risk by making them register as sex workers or obtain a license to engage in prostitution, and failing to end the illegal sex trade. ${ }^{54}$ Nevertheless, legalization and full decriminalization regimes both regulate prostitution as a form of work either through specific provisions ${ }^{55}$ or through general labor laws. ${ }^{56}$ They aim to end the stigma surrounding prostitution, improve the working conditions in which people are prostituted, and reduce violence in the sex trade. ${ }^{57}$

\section{Prostitution as Exploitation}

Advocates for the prostitution-as-exploitation position see prostitution as a form of institutionalized gender-based violence ${ }^{58}$ that most often occurs at the intersection of sexism, racism, classism, child abuse, and violence. ${ }^{59}$ In their view, those who are exploited should not be criminalized..$^{60}$ They support a partial decriminalization model,

Section II.A (explaining why the impacts of full legalization schemes are relevant in assessing the GottfriedSalazar bill).

${ }^{53}$ Marshall, supra note 52, at 56.

${ }^{54}$ Herrmann, supra note 23, at 90-92.

${ }^{55}$ See German Report on the Impact of the Prostitution Act, supra note 50, at 9.

${ }^{56}$ See Joelle Freeman, Legalization of Sex Work in the United States: An HIV Reduction Strategy, 32 Geo. J. LEgAL ETHICs 597, 603 (2019) (stating that in New Zealand, where full decriminalization was adopted, local councils regulate the sex trade through zoning and advertising restrictions).

${ }^{57}$ OPEn SOC'y Found., 10 ReASONS to DeCRiminalize SeX Work 1, 2-3, 6 (2015); Carvajal, supra note 51; GERMAN REPORT ON THE IMPACT OF THE PROSTITUTION ACT, supra note 50, at 9 (recounting that Germany's legalization framework was intended to improve the working conditions and social situation of people in prostitution and to reduce exploitation).

${ }^{58}$ MacKinnon, supra note 27, at 273-74.

${ }^{59}$ See Vednita Carter \& Evelina Giobbe, Duet: Prostitution, Racism and Feminist Discourse, 10 Hastings WOMEN's L.J. 37, 43 (1999).

${ }^{60}$ See, e.g., Taina Bien-Aimé, Why We Must Oppose the Full Decriminalization of Prostitution, Dignity: A J. on SeXual ExploitAtion \& Violence, July 2017, art. 10, at 2 (asserting that "full criminalization of prostitution fails to recognize the vulnerabilities of prostituted individuals and punishes them for their 
known as the "Nordic Model" about the issues surrounding prostitution, the creation of services for people in or exiting prostitution, and the need to hold pimps and prostitution buyers accountable for their role as exploiters. ${ }^{63}$

Some supporters of the prostitution-as-exploitation framework see paid sex as necessarily coerced by the money. ${ }^{64}$ Others argue that there likely is a certain number of "willing sex workers," but that, if necessary, the rights of those who are harmed by traffickers should be prioritized over the freedom to sell sexual access. ${ }^{65}$ Lastly, prostitution is viewed as harmful to women and society in general because it creates a barrier to gender equality. ${ }^{66}$

exploitation"); MacKinnon, supra note 12, at 20 (stating that through criminal prostitution laws "the state enforces the exploitation of prostituted women directly"); see also Carter \& Giobbe, supra note 59, at 56 (discussing the fact that Black women and girls, who are often unable to leave prostitution, should receive emotional support, advocacy services, and "tangible assistance to escape and overcome the trauma of commercial sexual exploitation").

${ }^{61}$ What Is the Nordic Model?, NORDIC MODEL Now!, https://nordicmodelnow.org/what-is-the-nordic-model/ [https://perma.cc/56PW-RP7R].

${ }^{62}$ Equality Model, New YorKers For THE EQUALITY Model, https://www.equalitymodelny.org/equalitymodel [https://perma.cc/6EES-UFRF].

${ }^{63}$ Mathieson et al., supra note 25, at 421-24.

${ }^{64}$ See MacKinnon, supra note 27, at 274 (stating that "the money coerces the sex rather than guaranteeing consent to it"); Carter \& Giobbe, supra note 59, at 51 (arguing that prostitution buyers exert power and control over people in prostitution).

${ }^{65}$ Donovan, supra note 24, at 610-12.

${ }^{66}$ Gunilla S. Ekberg, Swedish Laws, Policies and Interventions on Prostitution and Trafficking in HuMAN BeINGS: AN Overview 2 (2015). 


\begin{tabular}{|c|l|l|l|}
\hline $\begin{array}{c}\text { Comparative Chart of the Three Main Theories of Prostitution Discussed in This } \\
\text { Note and Their Corresponding Legislative Approaches }\end{array}$ \\
\hline $\begin{array}{c}\text { Theoretical } \\
\text { Approach }\end{array}$ & Prostitution-as-Sin & $\begin{array}{l}\text { Prostitution-as- } \\
\text { Work }\end{array}$ & $\begin{array}{l}\text { Prostitution-as- } \\
\text { Exploitation }\end{array}$ \\
\hline $\begin{array}{l}\text { Theoretical } \\
\text { Description }\end{array}$ & $\begin{array}{l}\text { Prostitution is a } \\
\text { victimless crime } \\
\text { caused by lack of } \\
\text { moral values. }\end{array}$ & $\begin{array}{l}\text { Prostitution is a type } \\
\text { of job that people } \\
\text { may choose freely } \\
\text { and that is not } \\
\text { inherently harmful. }\end{array}$ & $\begin{array}{l}\text { Prostitution is system of } \\
\text { oppression and a form of } \\
\text { institutionalized gender- } \\
\text { based violence. }\end{array}$ \\
\hline $\begin{array}{l}\text { Legislative } \\
\text { Approach }\end{array}$ & $\begin{array}{l}\text { Full } \\
\text { criminalization of } \\
\text { the sex trade, } \\
\text { including } \\
\text { prostitution, } \\
\text { buying, and } \\
\text { pimping }\end{array}$ & $\begin{array}{l}\text { Full legalization or } \\
\text { decriminalization of } \\
\text { the sex trade, } \\
\text { including } \\
\text { prostitution, buying, } \\
\text { pimping, and } \\
\text { brothels }\end{array}$ & $\begin{array}{l}\text { Decriminalization of } \\
\text { people in prostitution, } \\
\text { creation of services, } \\
\text { criminalization of buying, } \\
\text { pimping, and brothel } \\
\text { keeping, and education of } \\
\text { the public to issues } \\
\text { surrounding prostitution } \\
\text { ("Equality Model") }\end{array}$ \\
\hline $\begin{array}{l}\text { Relevant } \\
\text { Countries }\end{array}$ & $\begin{array}{l}\text { United States } \\
\text { (except Nevada) }\end{array}$ & $\begin{array}{l}\text { The Netherlands, } \\
\text { Germany, and New } \\
\text { Zealand }\end{array}$ & $\begin{array}{l}\text { Sweden and France } \\
\text { Swand }\end{array}$ \\
\hline
\end{tabular}

\section{B. International Legislative Approaches to Prostitution in the Twenty-First Century}

\section{Legalization and Full Decriminalization of the Sex Trade}

Many countries have a legal sex trade ${ }^{67}$ In some countries, regulated brothels are a legacy of colonization. ${ }^{68}$ In these instances, colonizing countries created health regulations to allow their soldiers and other men access to local and Indigenous women's

\footnotetext{
${ }^{67}$ See Countries Where Prostitution Is Legal 2020, WoRLD Population REVIEW, https://worldpopulationreview.com/country-rankings/countries-where-prostitution-is-legal [https://perma.cc/5TER-WT29].

${ }^{68}$ See infra note 69.
} 
bodies with a lower risk of contracting venereal diseases.$^{69}$ More recently, countries such as The Netherlands, Germany, and New Zealand have made prostitution and brothels legal to recognize prostitution as a form of labor in accordance with the prostitution-aswork theoretical position. ${ }^{70}$ These countries sought a legislative regime that would benefit the people in prostitution by giving them access to benefits ${ }^{71}$ and "end[ing] abuses in the sex industry." ${ }^{, 72}$ Nevertheless, prostitution often remains tied to a history of societal abuse of those who are prostituted. ${ }^{73}$ This Section examines the reforms instituted in each of these countries in turn.

\footnotetext{
${ }^{69}$ See, e.g., Christelle Taraud, La Prostitution Coloniale. Algérie, Maroc, Tunisie (1830-1962) [Colonial Prostitution. Algeria, Morocco, Tunisia] 19-22 (2003) (Fr.) (stating that in Algeria, Tunisia, and Morocco, French colonial authorities hyperregulated prostitution by creating military brothels, registering "indigenous" prostituted women, and requiring them to submit to weekly medical examinations). Today, brothel prostitution in Tunisia remains highly regulated and restricted to certain neighborhoods. Christina Omlin, Prostitution in Tunisia: The Big Reveal, QANTARA (Dec. 14, 2015), https://en.qantara.de/content/prostitution-in-tunisia-the-big-reveal [https://perma.cc/6HE4-UPTN]. In Senegal, French legislation enacted under colonization to prevent the spread of STDs remains in effect even after independence in 1960. W.B., Senegal's Innovative Approach to Prostitution, ECONOMIST (Apr. 12, 2018), https://www.economist.com/the-economist-explains/2018/04/12/senegals-innovative-approach-toprostitution [https://perma.cc/58YB-DLT7].

${ }^{70}$ See, e.g., German Report on the Impact of the Prostitution Act, supra note 50, at 9 (stating that the German government sought to "improv[e] conditions under which prostitutes work so as to benefit those ... who voluntarily earn their living by prostitution").

${ }^{71}$ Nisha Lilia Diu, Welcome to Paradise, TeL. (2013) (U.K.), https://s.telegraph.co.uk/graphics/projects/welcome-to-paradise/ [https://perma.cc/F5GZ-GL8H] (listing employment contracts, health insurance, and pension plans).

72 See Neth. Ministry of Foreign AfF., Dutch Policy on Prostitution 2 (2005), [hereinafter Dutch POLICY ON PROSTITUTION].

${ }^{73}$ Ever since British colonizers traveled to New Zealand in 1769, whalers, sealers, and traders "regularly exchanged items such as muskets for sexual access to Māori women." N.Z. PARLIAMENT, Prostitution LAW REFORM IN NEw ZEALAND (2012), https://www.parliament.nz/mi/pb/researchpapers/document/00PLSocRP12051/prostitution-law-reform-in-new-zealand/ [https://perma.cc/AH3V-8JAG] [hereinafter N.Z. PARLIAMENT].
} 


\section{a. The Netherlands}

In October 2000, the Dutch legislature made the sex trade legal, including brothels and pimping. ${ }^{74}$ The law imposed certain regulations on legal brothels. ${ }^{75}$ Regular medical checkups are not mandatory, but prostituted people are encouraged to have four medical checkups a year in order to protect themselves and their clients against sexually transmitted diseases. ${ }^{76}$ As a result of legalization, labor law applies to relations between prostituted people and their pimps. ${ }^{77}$

However, the Dutch government's prostitution policy has not accomplished its intended goals. The legalization of the brothel industry in the Netherlands has led to the growth of sex tourism into a major industry, as well as the increase of the illegal and unlicensed sex trade, sex trafficking, and demand. ${ }^{78}$ In recent years, cities such as Utrecht and Amsterdam have sought to close down window prostitution ${ }^{79}$ due to signs of human trafficking ${ }^{80}$ and the "humiliation of women by large groups of tourists." ${ }^{81}$ Further, the

\footnotetext{
${ }^{74}$ Dutch Policy on Prostitution, supra note 72, at 1.

${ }^{75}$ For example, the government required the installation of panic buttons and the provision of condoms. Id. at 2 .

${ }^{76} I d$. at 4 .

${ }^{77} \mathrm{Id}$. at 5. People who leave a job at a brothel may receive unemployment benefits if they had no choice but to stop working. See id. at 6 . Alternatively, they may receive social assistance if they exit the sex trade voluntarily. Id.

${ }^{78}$ See Julie Bindel, The Red Light District of Amsterdam Could Soon Be a Distant Memory-Here's Why, INDEP. (Feb. 13, 2018) (U.K.), https://www.independent.co.uk/voices/amsterdam-red-light-district-failingprostitution-sex-work-decriminalisation-doesnt-work-holland-a8206511.html [https://perma.cc/5HP5-RP3R] [hereinafter Bindel, The Red Light District of Amsterdam].

${ }^{79}$ Window prostitution is a form of indoor prostitution whereby women are displayed to passersby behind large windows. Window Prostitution, Red Light SECRETS, https://www.redlightsecrets.com/en/history/window-prostitution/ [https://perma.cc/4SWZ-2X7W].

${ }^{80}$ Utrecht mocht vergunning prostitutieboten 'oude' Zandpad intrekken, RAAD VAN STATE (Apr. 26, 2016) (Neth.), https://www.raadvanstate.nl/@8904/utrecht-mocht/ [https://perma.cc/HS6K-AVMK] (stating that Utrecht City Council withdrew licenses from all window brothels where trafficking victims might be prostituted).

${ }^{81}$ Senay Boztas, Amsterdam's First Female Mayor Plans to Shut the Windows on Red-Light District Gawkers, TEL. (July 3, 2019) (U.K.), https://www.telegraph.co.uk/news/2019/07/03/amsterdams-first-femalemayor-may-ban-red-light-windows-move/ [https://perma.cc/77V9-V4PH].
} 
mental health and quality of life of prostituted people has worsened, ${ }^{82}$ and the government provides barely any exit services. ${ }^{83}$

In 2008, the Dutch National Police Service published a report aimed at identifying the effectiveness of the country's prostitution and human trafficking policy. ${ }^{84}$ The report estimated that $50 \%$ to $90 \%$ of the women being bought and sold in window brothels were victims of human trafficking. ${ }^{85}$ The report posited that human trafficking was able to take place "almost unimpeded" in the licensed window prostitution sector ${ }^{86}$ because current policy, which relied on administrative controls such as licensing, was insufficient to identify and address every instance of human trafficking. ${ }^{87}$ Additionally, due to competing interests, the relevant actors lacked incentive to report and prosecute trafficking. ${ }^{88}$

\section{b. Germany}

Germany's Prostitution Act legalizing and regulating the sex trade came into effect in 2002. ${ }^{89}$ In 2007, a government report concluded that the Prostitution Act had not fully

\footnotetext{
82 See A.L. DaAlder, WOdC (Rsch. \& Documentation Ctr.), Prostitution in The Netherlands Since THE LIFTING OF THE BROTHEL BAN 71 (2007) (Neth.) (finding a decrease in emotional well-being and an increase in the use of sedatives).

${ }^{83}$ According to a 2007 study, only $6 \%$ of municipalities offered options for exiting prostitution. Id. at 70 .

${ }^{84}$ Dienst Nationale Recherche [Nat’l Crim. Intelligence Serv.], Schone Schijn: De Signalering van Mensenhandel in de Vergunde Prostitutiesector 10 (Politie, 2008) [hereinafter Dutch Police Report], https://www.yumpu.com/nl/document/view/19999831/schone-schijn-openbaar-ministerie [https://perma.cc/7YA6-SPNF].

${ }^{85} \mathrm{Id}$. at 84 . Law enforcement officials who conducted investigations estimated that $50 \%$ to $85 \%$ of the people prostituted in all legal brothels were prostituted under duress. Id. at 74-76.

${ }^{86} I d$. at $10-20$.

${ }^{87} \mathrm{Id}$. at 100 (stating that licensing did not guarantee that exploitation would not take place).

${ }^{88}$ For example, a prostitution buyer, noticing that the woman he is buying is being trafficked, might choose to ignore it. A social worker may choose not to disclose trafficking to the police in order to maintain a relationship of trust with the client. Because indications of human trafficking do not tend to be very clear, the police lack incentive to investigate trafficking cases under legalization and prefer to focus on other types of cases. Id. at 104-10.

${ }^{89}$ German Report on the Impact of the Prostitution Act, supra note 50, at 6.
} 
achieved its goals. ${ }^{90}$ The report recognized that few people had used the Act's legal framework to enable contracts of prostitution employment, that the Act did not lead to better working conditions for prostituted people in practice, and that the Act was not proven to have reduced crime. ${ }^{91}$ Nevertheless, the report also found that the Prostitution Act did not make it more difficult to prosecute trafficking or forced prostitution. ${ }^{92}$

Germany's prostitution policy has encouraged the growth of the sex trade and human trafficking. Researchers found a correlation between Germany's legalization of the sex trade and an increase in the number of international trafficking victims. ${ }^{93}$ According to a police inspector, prostitution has risen by up to $30 \%$ since $2002 .{ }^{94}$ It is estimated that over 400,000 people are prostituted in Germany, making it the country with the most prostituted people per capita. ${ }^{95}$ The legalization of brothels led to the creation of flat-rate mega-brothels, ${ }^{96}$ such as the "Pussy Club," which advertised "sex with all women as long as you want, as often as you want and the way you want." 97 The country attracts many sex tourists from neighboring countries. ${ }^{98}$ Recognizing the failure of the 2002

\footnotetext{
${ }^{90} I d$. at 79 .

${ }^{91} I d$.

${ }^{92} I d$.
}

${ }^{93}$ Seo-Young Cho, Axel Dreher \& Eric Neumayer, Does Legalized Prostitution Increase Human Trafficking?, WorLd DEV., Jan. 2013, at 69, 75; see also How Legalizing Prostitution Has Failed, SPIEGEL ONLINE (May 30, 2013) (Ger.), https://www.spiegel.de/international/germany/human-trafficking-persistsdespite-legality-of-prostitution-in-germany-a-902533.html [https://perma.cc/77HH-YXJG ] (stating that according to then-Munich Police Chief, human trafficking had largely increased and was difficult to investigate).

${ }^{94}$ Ingeborg Kraus, The "German Model", 17 Years after the Liberalization of Prostitution, Speech at the Italian Parliament in Rome (May 28, 2018).

${ }^{95}$ Diu, supra note 71 . In comparison, there are approximately 30,000 to 44,000 prostituted people in its neighboring country France. Les Députés votent pour la pénalisation des clients de prostituées [Representatives Vote for the Penalization of the Clients of Prostitutes], Monde (June 12, 2015) (Fr.), https://www.lemonde.fr/societe/article/2015/06/12/penaliser-les-clients-de-prostituees-la-proposition-de-loirevient-a-1-assemblee-nationale_4652633_3224.html [https://perma.cc/GR2E-SAAF].

${ }^{96}$ See Diu, supra note 71 (reporting on Paradise, a chain of German brothels that are around 15,000 square feet, and Pascha, a brothel in Cologne that is twelve stories high and receives 1,000 customers per day).

${ }^{97}$ How Legalizing Prostitution Has Failed, supra note 93 (stating that 1,700 men attended the opening weekend).

${ }^{98} \mathrm{Id}$. 
legislation, ${ }^{99}$ the German Parliament passed the "Prostitute Protection Act," which came into effect on July $1,2017 .{ }^{100}$ The new law creates certain health and labor regulations relating to prostitution ${ }^{101}$ and bans flat-rate brothels and gang-bangs. ${ }^{102}$ As of today, the legalization of the sex trade in Germany has not accomplished its intended goals.

\section{c. New Zealand}

In 2003, New Zealand became the first country to make the sex trade legal through full decriminalization. ${ }^{103}$ The Prostitution Reform Bill aimed to decriminalize prostitution activities and subject prostitution to special provisions, in order to give "sex workers ... the same protections afforded to other workers." 104 The Prostitution Reform Act (PRA) repealed the prohibition on soliciting in public places, imposed certain health and safety requirements, and created a brothel licensing system. ${ }^{105}$ In addition, the sex trade is regulated through local zoning and advertising restrictions. ${ }^{106}$ The PRA did not provide for any services for people in prostitution. ${ }^{107}$

\footnotetext{
${ }^{99}$ Germany: Prostitute Protection Laws Proving Impotent, DW (Feb. 18, 2019) (Ger.), $\mathrm{https} / / / \mathrm{www} . \mathrm{dw} . c 0 \mathrm{~m} / \mathrm{en} / \mathrm{germany}$-prostitute-protection-laws-proving-impotent/a-47560411 [https://perma.cc/C84C-UWDL].

${ }^{100}$ Fed. Ministry for Fam. Aff., Senior Citizens, Women and Youth, The new Prostitute Protection ACT 4 (2017), https://www.bmfsfj.de/blob/117624/ac88738f36935f510d3df8ac5ddcd6f9/prostschgtextbausteine-en-data.pdf [https://perma.cc/98S3-SHNR].

${ }^{101} I d$. at 4-6 (requiring registration, health consultations, condom use, and brothel licenses).

102 Germany Introduces Unpopular Prostitution Law, DW (July 2, 2017) (Ger.), $\mathrm{https} / / / \mathrm{www} . \mathrm{dw} . c 0 \mathrm{~m} / \mathrm{en} /$ germany-introduces-unpopular-prostitution-law/a-39511761 [https://perma.cc/Q7XT-T8W7].

${ }^{103}$ Prostitution Law Reform in New Zealand, supra note 73.

${ }^{104} I d$.

${ }^{105} I d$.

${ }^{106}$ Freeman, supra note 56, at 603.

107 Prostitution Reform Act 2003 (N.Z.), http://www.legislation.govt.nz/act/public/2003/0028/latest/DLM197815.html; [https://perma.cc/A6ENF5NC]; see also Georgia Forrester, Palmerston North's Haven to Help Former Sex Workers Officially Opens, STUFF (Jan. 18, 2017) (N.Z.), https://www.stuff.co.nz/national/88544958/palmerston-norths-haven-to-helpformer-sex-workers-officially-opens [https://perma.cc/45SW-82SY] (stating that a survivor founded the first refuge for people seeking to exit prostitution in 2017).
} 
A 2008 report on the effects of the PRA conducted by the Prostitution Law Review Committee, concluded that the legislation had overall "been effective in achieving its purpose," although "progress in some areas ha[d] been slow." 108 Noting the difficulties associated with accurately estimating the number of people in prostitution, the report concluded that the PRA had not caused an increase in the number of people in prostitution. ${ }^{109}$ The report determined that even though there had been an "apparent increase" in street prostitution in Auckland, there was no proof that it was caused by the PRA. ${ }^{110}$ At the same time, it found that according to a quantitative survey, one quarter of the respondents reported that decriminalization was one of their reasons for entering the sex trade. ${ }^{111}$ The report noted that "exploitative employment conditions" in the sex trade were still prevalent, that people in prostitution continued to experience violence - mostly committed by clients or men posing as clients - and that "there are still reports of sex workers being forced to take clients against their will." ${ }^{112}$

Critics question the reliability and impartiality of the 2008 report because of the weight that the New Zealand Prostitutes' Collective (NZPC) had on the investigations and findings. ${ }^{113}$ Various survivors of the New Zealand sex trade are critical of the current law and of the NZPC, ${ }^{114}$ and they estimate from their lived experience that prostitution

${ }^{108}$ N.Z Gov't, Report of the Prostitution Law Review Committee On the Operation OF the
Prostitution Reform Act 2003168 (2008) [hereinafter PRA Report].

${ }^{109}$ Id. at 29.

${ }^{110} I d$. at $40-41$.

${ }^{111} I d$. at 39.

${ }^{112} I d$. at 168 .

113 Janice G. Raymond, Gatekeeping Decriminalization of Prostitution: The Ubiquitous Influence of the New Zealand Prostitutes' Collective, Dignity: A Journal on Sexual Exploitation And Violence, Apr. 2018, art. 6, at 4-6 (Apr. 2018) (explaining that the NZPC played a central role in promoting the decriminalization of the sex trade and nominated three of the eleven members of the Prostitution Law Review Committee).

${ }^{114}$ Sabrinna Valisce criticizes the NZPC for offering condoms but not exit services. After the PRA came into effect, she realized that it actually gave prostituted women less power. See Julie Bindel, My Work as a Prostitute Led Me to Oppose Decriminalisation, BBC News (Oct. 2, 2017) (U.K.), https://www.bbc.com/news/magazine-41349301 [https://perma.cc/L58A-SVTH] [hereinafter Bindel, My Work as a Prostitute]. Ally-Marie Diamond, an Indigenous activist and survivor of the New Zealand sex trade, views prostitution as "terrorism against women." Raquel Rosario Sanchez, INTERVIEW: Women of Colour Speak out Against Prostitution, Feminist CurRent (Apr. 26, 2019) (Can.), https://www.feministcurrent.com/2019/04/26/interview-women-of-colour-speak-out-against-prostitution/ 
and sex trafficking have increased. ${ }^{115}$ While the number of large legal brothels may not have increased since 2003, these statistics do not include the number of small owneroperated brothels that do not require a license or consider the number of women who are prostituted. ${ }^{116}$ Despite the lack of objective, reliable data, it appears that New Zealand's decriminalization of prostitution may have led to the growth of the sex trade and has failed to end violence in the sex trade, similarly to legalization in Germany and the Netherlands.

\section{Decriminalization and Support of Prostitution Survivors Through the Equality Model}

In the past twenty years, several countries ${ }^{117}$ have adopted the prostitution-asexploitation position and enacted the Equality Model. ${ }^{118}$ This approach includes penalizing only pimps and prostitution buyers, funding social services, and educating the community about the harms of prostitution. ${ }^{119}$ Governments first conducted extensive

\footnotetext{
[https://perma.cc/4GFS-6FLS]. See also Raymond, supra note 113, at 9-10 (recounting the experiences of various survivors of the New Zealand sex trade); Survivor Stories, WAHINE ToA RISING, https://wahinetoarising.nz/survivors-stories/ [https://perma.cc/6CQH-B8RV] (sharing accounts from survivors in New Zealand).
}

${ }^{115}$ According to Chelsea, a New Zealand sex trade survivor, a mega-brothel was built in Auckland in recent years but has not yet opened. Julie Bindel, The Pimping of Prostitution: Abolishing the SeX Work Myth 124 (2017) [hereinafter Bindel, The Pimping of Prostitution]. Another survivor points out that there has been a massive increase in street prostitution and child sex trafficking in New Zealand since decriminalization. Ally-Marie Diamond, Testimony to D.C. City Council (Oct. 31, 2019) (on file with the author).

${ }^{116}$ Sabrinna Valisce, Full Decriminalization in New Zealand, SpaCe InT'L (June 8, 2018), https://www.spaceintl.org/media/full-decriminalization-in-new-zealand/ [https://perma.cc/L58A-SVTH]; see also Bindel, The Pimping of Prostitution, supra note 115, at 124 (explaining that some pimps operate by setting up several apartments for women to operate in "independently").

117 What Is the Nordic Model?, supra note 61 (stating that the Equality Model has been adopted in eight countries: Sweden, Norway, Iceland, Northern Ireland, Canada, France, Ireland, and Israel).

118 The Equality Model is also known as the Nordic or Swedish Model. See id. Through partial decriminalization, the government seeks to correct the inequality inherent to prostitution, wherein buyers exploit the coercive circumstances of prostituted people. See Waltman, supra note 32, at 450-51, 454.

119 See Equality Model, supra note 62; Mathieson et al., supra note 25, at 396-98. 
research on the impact of prostitution. ${ }^{120}$ For example, Israel adopted the Equality Model after conducting its first government survey about prostitution, which found that $95 \%$ of prostituted people in the country were women, the majority of whom were forced to remain in prostitution due to economic hardship. ${ }^{121}$

Countries have adopted the Equality Model in an attempt to reframe prostitution as an issue of gender-based inequality and violence. ${ }^{122}$ Their ultimate goal is to put an end to the system of prostitution and to allow any person who wishes to exit the sex trade to do so. ${ }^{123}$ This Section discusses the specifics of the Equality Model through the examples of Sweden and France. Sweden is the only country that adopted the Equality Model around the same time as the Netherlands and Germany legalized prostitution and therefore provides the best comparison in terms of available data. France's more recent law is used as an example of a broad version of the Equality Model, particularly with regard to support services and community education.

\section{a. Sweden}

In 1999, Sweden became the first country to enact the Equality Model. ${ }^{124}$ Sweden operates three "prostitution units" that offer free, comprehensive social services to people

\footnotetext{
${ }^{120}$ See Kajsa Ekis Ekman, Being and Being Bought: Prostitution, Surrogacy and the Split Self 17 19 (2014) (summarizing Swedish research conducted over two decades which led to the promulgation of the Swedish law); Guy Geoffroy, AsSEMBlÉE NATIONALE, RAPPORT D'INFORMATION SUR LA PROSTITUTION EN FRANCE 16 (2011) (Fr.), http://www.assemblee-nationale.fr/13/pdf/rap-info/i3334.pdf

[https://perma.cc/TLV6-T3K8] (presenting a 383-page report analyzing the status of prostitution in France, based on interviews with over 200 people).
}

${ }^{121}$ Lee Yaron \& Or Kashti, Prostitution in Israel Netted \$308 Million in 2014, First-ever Survey Finds, HAARETZ (Mar. 6, 2016) (Isr.), https://www.haaretz.com/israel-news/.premium-first-ever-survey-lifts-lid-onisraeli-prostitution-1.5413593 [https://perma.cc/7Q7K-DJPX]; Vered Lee, Israel's Law Against Prostitution Heralds a New Era of Gender Equality, HAARETZ (Jan. 1, 2019) (Isr.), https://www.haaretz.com/israelnews/.premium-anti-prostitution-law-heralds-new-era-of-gender-equality-1.6802521 [https://perma.cc/M8KN-9NPD].

122 See Waltman, supra note 32, at 451 (relating that Sweden's law criminalizing prostitution buyers was passed as part of a comprehensive bill on violence against women); Aliza Lavie, Moving Israel to the Forefront of Women's Rights, TIMES OF ISR. (Aug. 8, 2017), https://blogs.timesofisrael.com/moving-israel-tothe-forefront-of-womens-rights/ [https://perma.cc/5X62-G7V6] (stating that the Israeli law criminalizing prostitution buyers prioritizes women's rights).

${ }^{123}$ See, e.g., OLIVIER, supra note 38, at 29 (stating that the French law aims to combat the system of prostitution and give people in prostitution the financial, social, and legal means to exit prostitution).

${ }^{124}$ Mathieson et al., supra note 25, at 400. 
who are or have been in prostitution, without requiring that they exit the sex trade. ${ }^{125}$ These units also conduct outreach and community education. ${ }^{126}$ Prostitution buyers are fined according to a sliding scale based on their income, and they are offered voluntary counseling services. ${ }^{127}$

According to a report commissioned by the government, the number of Swedish prostitution buyers dropped from $12.7 \%$ to $7.6 \%$ between 1996 and $2008 .{ }^{128}$ Further, Sweden's prostitution population was estimated to have dropped from around 3000 to 650 people, making it eight to fifteen times smaller per capita than in neighboring countries. ${ }^{129}$ While acknowledging that there has been no study on the issue, critics of the Swedish law claim that it has led to increased danger in street-based prostitution, based on the fact that some people in prostitution expressed a fear of increased violence. ${ }^{130}$ The government report did not find any evidence that the legislation had "negative effects for individuals exploited in prostitution." 131 Overall, Sweden has succeeded in reducing the size of the sex trade and offering voluntary exit services.

\section{b. France}

In 2016, the French Parliament passed a comprehensive version of the Equality Model. ${ }^{132}$ In addition to penalizing the purchase or attempted purchase of sexual acts, the

${ }^{125} I d$. at $403-05$ (listing services such as financial assistance, counseling, medical services, and access to housing).

${ }^{126} I d$. at 404 .

${ }^{127}$ Id. at $407-08$.

${ }^{128}$ Waltman, supra note 32, at 460.

${ }^{129}$ Id. at 458-59 (comparing Sweden to Denmark and Norway).

${ }^{130}$ Susanne Dodillet \& Petra Östergren, The Swedish Sex Purchase Act: Claimed Success and DOCUMENTED EFFECTS 22 (2011). But see Waltman, supra note 32, at 460-62 (explaining the bias and lack of rigor of critics of the Swedish law, who selected a few interviewees based on their positive views of prostitution).

${ }^{131}$ EKBERG, supra note 66, at 36-37.

${ }^{132}$ Loi 2016-444 du 13 avril 2016 visant à renforcer la lutte contre le système prostitutionnel et à accompagner les personnes prostituées [Law 2016-444 of April 13, 2016 Aiming to Reinforce the Fight Against the System of Prostitution and to Assist Prostituted People], Journal Officiel DE LA République 
French law funds exit services for prostituted people, creates a specific immigration remedy, and provides for early education about the system of prostitution. ${ }^{133}$ Prosecutors can offer arrested buyers to take a class as an alternative to a fine. ${ }^{134}$ The first buyer arrests and awareness trainings, implemented in Fontainebleau, have led to a decrease in prostitution, driven by a decrease in demand. ${ }^{135}$

Under France's current laws, labor protections are available to people in prostitution. ${ }^{136}$ They can declare their earnings as independent workers and are eligible for unemployment benefits, health insurance, parental leave, family benefits, and retirement. ${ }^{137}$

In April 2018, Médecins du Monde and other organizations published a report criticizing the 2016 law for making prostitution less profitable and more dangerous. ${ }^{138} \mathrm{In}$ response, a collective of doctors signed a piece detailing the violence that people in prostitution have always endured. ${ }^{139}$ Supporters of the legislation further claim that the

Française [J.O.] [Official Gazette of France], Apr. 14, 2016, p. 1 (Fr.). Previously, French law only criminalized the purchase of sexual access to a minor or a particularly vulnerable person. Rapport d'évaluation sur l'application de la loi du 13 avril 2016 [Report on the Implementation of the Law of April 13, 2016], SÉNAT (Fr.), https://www.senat.fr/questions/base/2018/qSEQ180605430.html [https://perma.cc/K28L-29NE].

${ }^{133}$ Law 2016-444 of April 13, 2016, supra note 132, at art. 5-8, 18, 20.

${ }^{134} I d$. art. 21.

${ }^{135}$ Agnès Braik, Fontainebleau. Lutte contre la prostitution: quand le ressort judiciaire sert d'exemple, ACTU (Jan. 30, 2019) (Fr.), https://actu.fr/ile-de-france/fontainebleau_77186/fontainebleau-lutte-contreprostitution-ressort-judiciaire-sert-dexemple_21162694.html [https://perma.cc/8XTK-4NDG].

${ }^{136}$ Se Déclarer, STRASS (Jan. 2015), http://strass-syndicat.org/vos-droits/se-declarer/

[https://perma.cc/MX8M-GGNC] (explaining that earnings from prostitution can be declared under a category that includes the "services of prostitutes" or under more general categories, such as "other personal services").

${ }^{137} \mathrm{Id}$

${ }^{138}$ Helene Le BAIl ET AL., ENQUeTE SUR L'IMPACT DE LA LOI DU 13 AVRIL 2016 CONTRE LE “'SYSTEME PROSTITUTIONNEL" 6-7 (2018) (Fr.) (claiming that a reduction in the number of prostitution buyers led to a decrease in prices and an increase in risky behavior, particularly regarding the prevention of sexually transmitted diseases).

${ }^{139}$ Collective, Loi sur la prostitution: “Dépénaliser serait une catastrophe”, Monde (Jan. 9, 2019) (Fr.), https://www.lemonde.fr/idees/article/2019/01/09/loi-sur-la-prostitution-depenaliser-serait-unecatastrophe_5406832_3232.html [https://perma.cc/WP6N-FGD7]. 
law has not been sufficiently implemented for its large-scale effects to be perceived. ${ }^{140}$ While perhaps it is too early to fully measure the impacts of the French law, it provides an example of an attempt to address the system of prostitution as a whole through broad legislative reform.

\section{American Prostitution Policy and the Gottfried-Salazar Bill}

\section{Prostitution Policy in the United States}

In the United States, federal law can only regulate prostitution with a jurisdictional hook. ${ }^{141}$ Prostitution is regulated by states under the police power. ${ }^{142}$ Most states criminalize prostitution in accordance with the prostitution-as-sin position. ${ }^{143}$ Two exceptions to this approach include Nevada, where prostitution in licensed brothels is authorized in counties with a population of less than 700,000 people, ${ }^{144}$ and Rhode Island, where the indoor sex trade was briefly decriminalized from 2003 to $2009 .{ }^{145}$

Some states and counties have adapted their policies to better address exploitation, although prostitution remains criminalized. For example, the First Offender Prostitution Program was founded in San Francisco in 1995 to address the high rates of violence,

\footnotetext{
${ }^{140}$ Christine Blec, La loi a de premiers effets positifs. Il faut aller plus loin, PROSTITUTION ET SociéTÉ (Fr.), http://prostitutionetsociete.fr/actualites/actualites-france/article/la-loi-a-de-premiers-effets-positifs-il-fautaller-plus-loin [https://perma.cc/LGC8-HYN9] (stating that only a few departments in France arrest buyers).

${ }^{141}$ See 18 U.S.C. $§ 2422$ (2018) (prohibiting the persuasion of another to travel across state lines for prostitution).

${ }^{142}$ Cherry v. Koch, 491 N.Y.S.2d 934, 944 (Sup. Ct. 1985), modified, 514 N.Y.S.2d 30 (App. Div. 1987), appeal denied, 70 N.Y.2d 603 (1987).

${ }^{143}$ See supra note 28 and accompanying text. The condemnation of prostitution in the United States has its origins in Protestant morals. See Aaron D. Simowitz, How Criminal Law Shapes Institutional Structures: A Case Study of American Prostitution, 50 AM. CRIM. L. REV. 417, 422 (2013). States began entirely prohibiting prostitution in the early twentieth century, following a report about the evils of prostitution published in 1911. Id. at 432-33.

${ }^{144}$ NeV. ReV. StAT. § 244.345 .8 (2019).

${ }^{145}$ Scott Cunningham \& Manisha Shah, Decriminalizing Indoor Prostitution: Implications for Sexual Violence and Public Health, REV. ECON. STUD., July 2018, at 1683, 1684.
} 
poverty, and health problems in prostitution. ${ }^{146}$ This program focuses on prevention and intervention services for prostituted people, as well as education of prostitution buyers, and systemic reform. ${ }^{147}$ Seattle has shifted the prosecution of prostitution crimes from prostituted women to pimps and buyers ${ }^{148}$ and implemented a ten-week program designed to educate prostitution buyers about the sex trade. ${ }^{149}$ Programs that focus on educating buyers, known as "john schools," aim to reintegrate offenders through behavioral change. ${ }^{150}$

In a similar vein, the New York judiciary created Human Trafficking Intervention Courts (HTICs) in 2013, in an effort to identify victims of trafficking and provide them with services. ${ }^{151}$ A defendant is referred to an HTIC after a prostitution arrest. ${ }^{152}$ Most HTIC cases are resolved with an adjournment in contemplation of dismissal (ACD), ${ }^{153}$ which often includes an obligation to complete several sessions with a social-service provider. ${ }^{154}$ Considering that current laws in New York criminalize prostitution, ${ }^{155}$ the

\footnotetext{
${ }^{146}$ First Offender Prostitution Program, Gov. InNOvators Network, https://www.innovations.harvard.edu/first-offender-prostitution-program [https://perma.cc/7NVX-P72M].

${ }^{147} I d$.

${ }^{148}$ Mathieson et al., supra note 25, at 419-20.

${ }^{149} I d$. at $420-21$.

${ }^{150}$ Robin Malony Valenzuela, The Nashville John School: Risk Deterrence and the Reintegrative Shaming Approach 48 (Apr. 19, 2013) (M.A. thesis, University of Louisville) (available at https://ir.library.louisville.edu/etd/1480/ [https://perma.cc/9NQJ-596E]) (stating that john schools aim to reintegrate, rather than stigmatize offenders).
}

${ }^{151}$ Announcement of New York's Human Trafficking Intervention Initiative, CTR. FOR CT. INNOVATION (Oct. 4, 2013), https://www.courtinnovation.org/articles/announcement-new-yorks-human-trafficking-interventioninitiative [https://perma.cc/53RX-6J7W] (quoting Jonathan Lippman, New York State Chief Judge).

152 See Herrmann, supra note 23, at 86.

${ }^{153}$ As of April 26, 2019, the HTICs had disposed of 13,852 cases since their inception. 7,708 cases ended in an ACD, and 2,109 were dismissed. N.Y.S. UNIFIED CT. Sys., HuMAN TrAFFiCKING INTERVENTION COURTS Dispositions Since InCEPTION (QueEns 11/4/2010, OtHeRs 9/25/2013) AS OF 4/26/2019 (on file with the author).

${ }^{154}$ Aya Gruber, Amy J. Cohen \& Kate Mogulescu, Penal Welfare and the New Human Trafficking Intervention Courts, 68 FLA. L. REv. 1333, 1366-67 (2016) (listing services such as counseling and access to benefits).

${ }^{155}$ See N.Y. Penal Law $§ 230.00$ (McKinney 2019). 
HTICs are at least partially successful ${ }^{156}$ in modifying the application of antiquated laws to accomplish modern goals focusing on "rehabilitation and renewal." 157 However, they have been criticized as overly coercive, ${ }^{158}$ inherently contradictory, ${ }^{159}$ and an example of the limits of using the criminal legal system to provide services. ${ }^{160}$ Many people today agree that a better solution would be to recognize that people in prostitution should not be criminalized. ${ }^{161}$

Until recently, New York State law also criminalized loitering for purposes of prostitution. ${ }^{162}$ This statute, commonly referred to as the "walking while trans" ban, ${ }^{163}$ was often used in a discriminatory manner, as police disproportionately targeted Black women, other people of color, and transgender women. ${ }^{164}$ On February 2, 2021, a bill

\footnotetext{
${ }^{156}$ Gruber et al., supra note 154, at 1366-67 (acknowledging that "[m]ost HTIC stakeholders . . . seem to agree that ... post-HTIC programming is relevant to defendants' lives, even beneficial").

${ }^{157}$ CTR. FOR CT. INNOVATION, supra note 151 (quoting Jonathan Lippman).

${ }^{158}$ Gruber et al., supra note 154, at 1368 (according to Zoe Root, Attorney, Bronx Defs., "[W]hen participation in services is coerced with an arrest and the threat of jail time, the client is disempowered, and the good intentions backfire."). Furthermore, prosecutors might encourage prostitution defendants to cooperate in trafficking cases by offering to dismiss the case, even when disclosure of trafficking may place the defendant in danger. See id. at 1375.
}

${ }^{159}$ HTICs aim to treat defendants as victims rather than criminals. This leads to "the idea of the victimdefendant," which some argue does both too much — by incarcerating a defendant to protect her from her trafficker - and too little - by repeatedly arresting trafficking victims on prostitution charges. Id. at 1359-60.

${ }^{160}$ Gruber criticizes penal welfare, pointing out that it requires "demeaning and invasive arrests, criminal processing, and the threat of incarceration" and that it might discourage the state from developing welfare systems elsewhere. Id. at 1402 .

${ }^{161}$ See Herrmann, supra note 23; MacKinnon, supra note 12, at 20, 25; Michelle Madden Dempsey, Decriminalizing Victims of Sex Trafficking, 52 AM. CRIM. L. REv. 207, 216-23 (2015); Mathieson et al., supra note 25, at 374-78; Timothy Williams, In Washington, a Fight to Decriminalize Prostitution Divides Allies, N.Y. Times (Oct. 17, 2019), https://www.nytimes.com/2019/10/17/us/washington-legalprostitution.html [https://perma.cc/XB5N-XUSX].

162 N.Y. Penal Law § 240.37 (McKinney 2019) (repealed 2021).

163 Jaclyn Diaz, New York Repeals 'Walking While Trans' Law, NPR (Feb. 3, 2021), https://www.npr.org/2021/02/03/963513022/new-york-repeals-walking-while-trans-law [https://perma.cc/7VZR-VMZV].

${ }^{164}$ See Herrmann, supra note 23, at 102-05 (noting racial and gender biases in arrests under the loitering statute). 
repealing the anti-loitering statute was signed into law. ${ }^{165}$ Around the same time, several district attorneys in New York City have taken steps towards ending the criminalization of people in prostitution. At the end of January 2021, Brooklyn District Attorney Eric Gonzalez announced that he had vacated 262 arrest warrants involving prostitution charges and was moving to dismiss 850 cases that dated back to the $1970 \mathrm{~s} .{ }^{166} \mathrm{He}$ also asked state legislators to expunge thousands of prostitution-related convictions in Brooklyn since 1975. ${ }^{167}$ Similarly, on March 16, 2021, Judge Toko Serita dismissed and sealed hundreds of Queens prostitution-related cases were following a request by District Attorney Melinda Katz. ${ }^{168}$ Most recently, on April 21, 2021, the office of Manhattan District Attorney Cy Vance became the first in the state to announce a formal policy to stop prosecuting arrests for prostitution or unlicensed massage. ${ }^{169}$

\section{The Gottfried-Salazar Bill: A Proposal to Fully Decriminalize the Sex Trade}

Similarly to the legalization and decriminalization schemes explored in Section I.B.1, the Gottfried-Salazar bill seeks to decriminalize the sex trade in New York by repealing criminal provisions against prostitution, prostitution buying, promoting the prostitution of a person who is over eighteen years old, and running brothels and other commercial sex establishments. ${ }^{170}$ The bill also modifies the mens rea for advancing prostitution, from a requirement of knowledge ${ }^{171}$ to one of intent. ${ }^{172}$ This increases the level of mens rea for

${ }^{165}$ Diaz, supra note Error! Bookmark not defined..

${ }^{166}$ Amy Yensi, Brooklyn DA Dismisses Hundreds of Prostitution Arrests, SPECTRUM News (Jan. 29, 2021), https://www.ny1.com/nyc/all-boroughs/news/2021/01/30/brooklyn-da-dismisses-hundreds-of-prostitutionarrests [https://perma.cc/G3ZM-XB92].

${ }^{167} I d$.

168 David Brand, Queens Court Dismisses Hundreds of Prostitution Cases After Request from DA, QUEENS DAILy EAGLE (Mar. 16, 2021), https:/queenseagle.com/all/queens-court-dismisses-hundreds-of-prostitutioncases-after-request-from-queens-da [https://perma.cc/8NFX-V99D].

${ }^{169}$ Manhattan DA Will No Longer Prosecute Prostitution Arrests, NBC N.Y. (Apr. 21, 2021), https://www.nbcnewyork.com/news/local/crime-and-courts/manhattan-da-will-no-longer-prosecuteprostitution-arrests/3011704/ [https://perma.cc/52R4-X4L9].

${ }^{170}$ Sen., S3075, 2020-2021 Sess. (N.Y. 2020) pt. A.

${ }^{171}$ N.Y. PENAL LAW $§ 230.15$ (McKinney 2019).

172 N.Y. Sen. S3075 § A.1. 
the crimes of promoting the prostitution of children, ${ }^{173}$ compelling prostitution,,${ }^{174}$ and permitting prostitution. ${ }^{175}$ The Gottfried-Salazar bill creates an exception for defendants under twenty-one years of age, under which their conduct only constitutes "advancing prostitution" if they participated in forced prostitution or sex trafficking. ${ }^{176}$

The bill is currently in the Senate and Assembly Codes Committees. ${ }^{177}$ As of May 28, 2021, it is sponsored by seven senators and sixteen Assembly members. ${ }^{178}$ Proponents of the bill argue that full decriminalization will decrease trafficking and increase the legal rights of sex workers. ${ }^{179}$ Critics maintain that the bill would only legalize the "indescribable violence" committed by pimps and buyers, because prostitution is "an inherently harmful practice, rooted in gendered violence and discrimination based on sex and race." ${ }^{180}$ An alternative bill seeking to introduce the Equality Model in New York State through the "Sex Trade Survivors Justice and Equality Act" was introduced in 2021 by Senator Liz Krueger and Assembly Member Pamela Hunter. ${ }^{181}$

${ }^{173}$ PENAL $\S 230.30$ (criminalizing advancing prostitution of a person less than eighteen years old); Id. $\S 230.32$ (criminalizing advancing prostitution of a person less than thirteen years old).

${ }^{174} I d$. $\S 230.33$ (criminalizing advancing prostitution of a person less than eighteen years old by compelling the person to engage in prostitution by force or intimidation).

${ }^{175} I d$. $\S 230.40$ (criminalizing permitting prostitution in premises or a vehicle that are being used for the purpose of advancing prostitution).

${ }^{176}$ N.Y. Sen. S3075 § A.10.

177 Senate Bill S3075, NYSENATE.GOv, https://www.nysenate.gov/legislation/bills/2021/s3075 [https://perma.cc/4QDV-PNZZ]; Assembly Bill A849, NYSENATE.GOV, https://www.nysenate.gov/legislation/bills/2021/a849 [https://perma.cc/45TU-H7NZ].

${ }^{178}$ Senate Bill S3075, supra note 177; Assembly Bill A849, supra note 177.

${ }^{179}$ Raven, supra note 7.

${ }^{180}$ Melanie Thompson, Legalize Prostitution? Hell No, DAILy News (Mar. 1, 2019), https://www.nydailynews.com/opinion/ny-oped-decriminalize-sex-work-hell-no-20190228-story.html.

${ }^{181}$ Senate Bill S6040, NYSENATE.GOv, https://www.nysenate.gov/legislation/bills/2021/S6040 [https://perma.cc/5KTN-S2SV]; Assembly Bill S7069, NYSENATE.GOV, https://www.nysenate.gov/legislation/bills/2021/a7069 [https://perma.cc/AT9M-HFUC]; Megan Cerullo, New York Bill Would Decriminalize People in Prostitution, Punish Pimps and Buyers, CBS News (last updated Jan. 26, 2021), https://www.cbsnews.com/news/new-york-bill-decriminalize-sex-work/ 
The Gottfried-Salazar bill has been described as "the most comprehensive decriminalization effort ever initiated in the United States." ${ }^{182}$ It expands upon similar proposals introduced in other states. ${ }^{183}$ In considering how to update their laws regarding prostitution, states should take into account the impact of the various reforms in other countries. Part II proposes such an analysis by predicting whether the Gottfried-Salazar bill is likely to accomplish its stated objectives, considering the results of similar legal regimes in other countries.

\section{A Comparative Analysis of the Gottfried-Salazar Bill}

This Part adopts comparative analysis to argue that the Gottfried-Salazar bill would likely fail to accomplish many of its objectives. Section A demonstrates that examples of both legalization and decriminalization schemes are relevant to this analysis. Section B shows that based on what has happened in other countries, the implementation of the Gottfried-Salazar bill is unlikely to accomplish its goals. Section $\mathrm{C}$ argues that the bill would likely cause prostitution and sex trafficking to increase and make the enforcement of anti-trafficking laws more difficult.

[https://perma.cc/V72P-2GH4]; see also Cristian Eduardo, Commentary: For survivors of sex trafficking, a path toward justice and hope, Times UNION (Apr. 7, 2021),

https://www.timesunion.com/opinion/article/Commentary-For-survivors-of-sex-trafficking-a-16010356.php [https://perma.cc/22YT-RUEY] (explaining that the proposed legislation was developed by working with survivors of the sex trade and would decriminalize people in prostitution, expand social services, and hold accountable pimps and prostitution buyers). This Note was primarily drafted before the Hunter-Krueger bill was introduced and therefore does not include an analysis of the Hunter-Krueger bill.

182 Jesse McKinley, Bills to Decriminalize Prostitution Are Introduced. Is New York Ready?, N.Y. TimES (June 11, 2019), https://www.nytimes.com/2019/06/11/nyregion/prostitution-legal-ny.html

[https://perma.cc/8XPS-AZJK].

${ }^{183}$ See supra note 22; see also Marissa J. Lang, D.C. Effort to Decriminalize Sex Work Won't Move Forward after 14-Hour Hearing, WASH. POST (Nov. 17, 2019), https://www.washingtonpost.com/local/dc-politics/dceffort-to-decriminalize-sex-work-wont-move-forward-after-tense-14-hour-hearing/2019/11/16/b7c7735806ef-11 ea-ac12-3325d49eacaa_story.html [https://perma.cc/59GB-7NDP] (reporting that a bill introduced in Washington, D.C., did not move forward). 


\section{A. The Commonalities Between the Gottfried-Salazar Bill and Legalization Schemes}

\section{Formal Similarities Between the New York Bill and the German and Dutch Laws}

Proponents of the Gottfried-Salazar bill recognize that legalization regimes, such as those enacted in Nevada and the Netherlands, empower pimps and disempower prostituted people. ${ }^{184}$ They distinguish the decriminalization regime proposed by the bill. ${ }^{185}$ However, legalization and decriminalization schemes share many formal similarities. The New York bill decriminalizes the sex trade entirely by repealing the provisions of the Penal Code prohibiting brothels and pimping. ${ }^{186}$ Similarly, the Dutch law repealed provisions against brothels and pimping. ${ }^{187}$

The Dutch legislature left it to local authorities to regulate brothels and street prostitution, and to issue licenses. ${ }^{188}$ In the same way, when the sex trade was decriminalized in New Zealand, territorial authorities were authorized to make bylaws regulating brothels and advertising. ${ }^{189}$ The Gottfried-Salazar bill does not include any provisions for regulating brothels or prostitution. ${ }^{190}$ By default, local authorities such as city councils would therefore be left with the authority to create certain regulations. ${ }^{191}$ The implementation of a legal sex trade in New York would resemble the regimes adopted in both legalization and decriminalization regimes.

\footnotetext{
${ }^{184}$ See Raven, supra note 7.

${ }^{185}$ See id.; see also Press Release, DeCRIM NY, supra note 16 (quoting Senators Julia Salazar and Jessica Ramos) (stating that the objective of the Gottfried-Salazar bill is to "empower sex workers in their workplaces").

${ }^{186}$ Sen., S3075, 2020-2021 Sess. (N.Y. 2020), § A.10.

${ }^{187}$ Dutch Policy on Prostitution, supra note 72, at 1.

${ }^{188} I d$. at $1-2$.

${ }^{189} I d$. at 2.

${ }^{190}$ See N.Y. Sen. S3075.

${ }^{191}$ New York municipalities can require licenses for adult entertainment businesses. See, e.g., CITY OF YoNKERS CODE $§ 43-74(G)$ (2018) (requiring special use permits for sexually oriented businesses); CiTY OF ROCHESTER CODE $§$ 98-4 (2020) (requiring a specific license for both operators and employees of sexually oriented businesses).
} 


\section{The Inevitable Regulation of Prostitution Under the Gottfried- Salazar Bill}

Advocates of the Gottfried-Salazar bill claim that regulation creates an unfair distinction between people prostituting legally, who are protected by laws, and those prostituting illegally, who are the most marginalized. ${ }^{192}$ However, decriminalizing the sex trade in New York would necessarily engender some regulation of brothels and prostituted people, which would lead to the same distinction between people who are prostituting legally and those who are not.

Under the Gottfried-Salazar bill, general labor and private laws that apply in New York would regulate prostitution. ${ }^{193}$ In some localities, current zoning laws regulating "adult businesses" would apply to brothels. ${ }^{194}$ For example, the Yonkers municipal code includes any "establishment which provides ... forms of entertainment that involve specified sexual activities" in its definition of "adult commercial establishment."195 Municipalities throughout the state impose strict zoning regulations on such businesses. ${ }^{196}$ If brothels were decriminalized, prostitution businesses that do not respect these zoning restrictions would therefore be operating illegally. People prostituting in their own homes would likely be violating the zoning regulations, ${ }^{197}$ whereas pimps who

\footnotetext{
192 See Raven, supra note 7.

${ }^{193}$ In the Netherlands, relations between prostituted people and pimps are regulated by labor and other private laws. Dutch Policy on Prostitution, supra note 72, at 5-6. Similarly, in New Zealand, "the laws pertaining to sex work are the same as those for other workplaces," and "sex workers ... have the same labour rights as workers in other occupations." The New Zealand Model, N.Z. Prostitutes' Collective, https://www.nzpc.org.nz/The-New-Zealand-Model [https://perma.cc/Z7F9-QGCA].
}

${ }^{194}$ N.Y.S. Off. of Gen. Counsel, Legal Memorandum LU03, Municipal Regulation of Adult Uses.

${ }^{195}$ City OF YonKers Code $§ 43-8$ (2018).

196 See, e.g., Buff. Green Code Unified Dev. Ordinance, 152, 57 (2016),

https://www.buffalony.gov/DocumentCenter/View/1785/Buffalo-Green-Code---Unified-DevelopmentOrdinance-PDF?bidId= [https://perma.cc/9N9S-W96P] (designating only the two industrial zones as those where adult establishments are allowed and prohibiting adult establishments from being located within 750 feet of a residential zone, a place of worship, a community center, a school, a day care center, or a public park).

${ }^{197}$ Many zoning regulations prohibit adult establishments from operating within or near a residential zone. See id. at 157; City of Albany Unified Dev. Ordinance § 375-3(C)(4)(e)(i) (2017); Vill. OF Lewiston CODE app. B § 10.Q.7 (2019). 
can afford to rent out a space that respects all the zoning regulations would be operating legally.

Further, regulations imposed by local authorities ${ }^{198}$ might result in a distinction between legal and illegal brothels. ${ }^{199}$ Therefore, under full decriminalization, the most marginalized people in prostitution would likely still be exploited underground and illegally, despite claims that this result only occurs under full legalization or criminalization schemes. ${ }^{200}$ Likewise, a person who does not have a work permit, such as someone who does not have immigration status or an international student, would not have the right to make money in prostitution, or be protected by labor laws. ${ }^{201}$ Implementing the Gottfried-Salazar bill would result in a distinction between people prostituting legally and those prostituting illegally. International examples of both decriminalization and legalization schemes adopted in pursuit of similar objectives as the Gottfried-Salazar bill are therefore relevant in assessing the likely effects of the bill.

\section{B. Stigma, Abusive Working Conditions, and Violence Under Full Decriminalization}

The Gottfried-Salazar bill aims to bring prostitution out of the shadows, to improve access to workers' rights for prostituted people, and to reduce violence and

\footnotetext{
${ }^{198}$ See supra note 191 and accompanying text.

${ }^{199}$ Local authorities might create a licensing process in order to control who is eligible to own or operate a brothel. See, e.g., Brothel Operator Certification, N.Z. MINISTRY OF JUST.,

https://www.justice.govt.nz/licences-certificates/brothel-operator-certification/apply-for-a-brothel-operatorcertificate/ [https://perma.cc/4Y4Q-DP6A] (stating that to obtain a license in New Zealand, a person must be over eighteen, be a New Zealand or Australian citizen or permanent resident and pass a criminal record check).
}

${ }^{200}$ See Raven, supra note 7; Marshall, supra note 52, at 57, 62 (criticizing the German legalization model because it allows local zoning and registration regulations and police enforcement, resulting in "some of the worst harms of criminalization." Assembly Member Gottfried criticizes the current criminalization of prostitution in that it forces prostituted people to work underground and illegally, which causes increased violence, abuse, and exploitation. Press Release, DeCRIM NY, supra note 16 (quoting Assembly Member Gottfried).

${ }^{201}$ See N.Z. MiNISTRY OF JUST., supra note 199 (stating that New Zealand law requires a person to have citizenship or permanent residence in order to "provide commercial sexual services"). 
exploitation. ${ }^{202}$ However, fully decriminalizing the sex trade is unlikely to accomplish these goals.

\section{Full Decriminalization Would Not End the Stigma Against People in Prostitution}

The Gottfried-Salazar bill is unlikely to put an end to the stigma against prostituted people. Other jurisdictions have failed to end the stigma against people in prostitution through decriminalization. In New Zealand, the stigma around prostitution persisted following the enaction of the PRA. ${ }^{203}$ In Amsterdam, window brothels still enable "the humiliation of women by large groups of tourists." ${ }^{204}$ The stigma around prostitution cannot be legislated away. ${ }^{205}$

Moreover, the argument that decriminalizing the sex trade entirely will eliminate the stigma against prostituted people presupposes that the stigma stems solely from the criminalization of prostitution and the refusal to consider it a legitimate line of work. ${ }^{206}$ However, the fact that women who are prostituted legally are also stigmatized ${ }^{207}$ demonstrates that the stigma against them does not stem solely from criminalization. People who are prostituted often end up in prostitution as a continuation of their oppression fueled by the intersection of gender, race, and class. ${ }^{208}$ Thus, their exploitation

\footnotetext{
${ }^{202}$ Press Release, DeCRIM NY, supra note 16 (quoting Senator Julia Salazar and Assembly Member Gottfried).
}

${ }^{203}$ See Prostitution Law Reform in New Zealand, supra note 73 (referring to findings from a 2008 report).

${ }^{204}$ Amsterdam's Mayor: 'Prostitutes Should Not Be a Tourist Attraction', Dutch News (Feb. 11, 2019) (Neth.), https://www.dutchnews.nl/news/2019/02/amsterdams-mayor-prostitutes-should-not-be-a-touristattraction/ [https://perma.cc/Z6F2-VYHR] (quoting Amsterdam Mayor Femke Halsema).

205 Thomas Manch, New Zealand's Sex Industry Model 'as Useful as a Burst Condom', STUFF (Oct. 15, 2017) (N.Z.), https://www.stuff.co.nz/business/industries/97760559/new-zealands-sex-industry-under-fire-as-nzpccelebrates-30 ${ }^{\text {th }}[$ https://perma.cc/Q4UJ-H4DG].

${ }^{206}$ See, e.g., Jenness, supra note 48, at 416 (explaining that some argue that "prostitution is work ... [that] should be ... destigmatized ... as work like any other type of service work).

${ }^{207}$ See supra notes 205-204.

${ }^{208}$ See supra note 59 and accompanying text. 
in prostitution for the pleasure of men $^{209}$ becomes an integral part of their marginalization. ${ }^{210}$ Legally sanctioning the men who pay to use women for their sexual pleasure is not a viable solution to the prostitution stigma. ${ }^{211}$

\section{Full Decriminalization Would Not Lead to Adequate "Working Conditions"}

Decriminalizing the sex trade in New York is very unlikely to lead to adequate "working conditions" or labor protections for people who are prostituted. Similarly to the New Zealand law, the Gottfried-Salazar bill would give more power to pimps and brothel owners, as they would no longer be criminalized if it were enacted. ${ }^{212}$ Because the Gottfried-Salazar bill does not prohibit flat rates, ${ }^{213}$ brothels would be able to legally offer "all inclusive" deals as they did in Germany ${ }^{214}$ and New Zealand. ${ }^{215}$ In practice, women who are prostituted in New York brothels would not have control over the sexual acts they must perform for a set rate. ${ }^{216}$

\footnotetext{
${ }^{209}$ See Rachel Moran \& Melissa Farley, Consent, Coercion, and Culpability: Is Prostitution Stigmatized Work or an Exploitive and Violent Practice Rooted in Sex, Race, and Class Inequality?, ARCHIVES OF SeXual BeHAVIOR, Feb. 2019, at 1947 (quoting the critique of prostitution by Swedish Minister Margareta Winberg as the treatment of "certain women and children, ... often those who are most economically and ethnically marginalized, ... as a lower class, whose purpose is to serve men sexually").

${ }^{210}$ See Nelson Butler, supra note 36, at 125 (suggesting that sexual exploitation through prostitution participates in the racial subordination of people of color in the United States).

${ }^{211}$ See MacKinnon, supra note 27, at 274 (arguing that the inherent inequality of the prostitution transaction, by which money coerces sex, is largely responsible for the stigma of prostitution).

${ }^{212}$ See S. 3075, 2020-2021 Reg. Sess. (N.Y. 2020), supra note 14, § A.10 (proposing to repeal sections 230.20 and 230.25 of the New York Penal Law); Bindel, The Pimping of Prostitution, supra note 115, at 101 (stating that, according to New Zealand sex trade survivor Sabrinna Valisce, decriminalization gave less power to the people in prostitution and more power to the brothel owners).

${ }^{213}$ See S. 3075, 2020-2021 Reg. Sess. (N.Y. 2020).

${ }^{214}$ See supra note 97 and accompanying text.

${ }^{215}$ See Valisce, supra note 116 (reporting that following decriminalization in New Zealand, brothels all began offering "all-inclusives," by which prostitution buyers pay a flat rate determined by the brothel for all sexual acts).

${ }^{216}$ See id.
} 
Under decriminalization and legalization regimes, prostituted people are often considered independent contractors with regard to taxes and labor laws, even though they are controlled as employees. ${ }^{217}$ As the Gottfried-Salazar bill does not limit the fees and rules that brothels can impose on prostituted people or require them to be considered employees, ${ }^{218}$ brothels would likely set work hours, prices, and a dress code, ${ }^{219}$ all the while declaring the workers as independent contractors unprotected by labor and employment laws.

Additionally, the decriminalization of the sex trade would almost certainly lead to a decrease in prices for prostitution acts. ${ }^{220}$ The people in prostitution would be negatively affected by the decrease in prices, as they often enter the sex trade due to a lack of resources. ${ }^{221}$ The Gottfried-Salazar bill does not allocate any funding for services for

\footnotetext{
${ }^{217}$ See, e.g., Ally-Marie Diamond (@AllyMDiamond), TwitTER (Feb. 9, 2020, 5:52 AM), https://twitter.com/AllyMDiamond/status/1226458949655785474 [https://perma.cc/QNU8-WB2T] (sharing a New Zealand brothel's form stating that the "working girl" is an independent contractor and is responsible for covering her own taxes, in addition to shift fees, advertising fees, potential penalty fees, and a three-hundred dollar bond); Valisce, supra note 116 (explaining that as independent contractors, prostituted people do not receive labor protections such as paid leave, healthcare, retirement benefits, or a union, but that brothel owners generally control prices, determine work hours, and set strict dress codes); Bingham, supra note 27, at 93-94, 96, 98 (stating that in Nevada, people who are prostituted in brothels are unable to assert rights as employees because they are considered independent contractors, but that they cannot choose the hours they work, the prices they charge, or the men by whom they are bought).
}

${ }^{218}$ See N.Y. Sen. S3075.

${ }^{219}$ See Helmut Sporer, Detective Chief Superintendent, Augsburg Crimes Squad, Speech for the Seminar "Reality of Prostitution" of the European Women's Lobby 2-3 (Oct. 1, 2013) (relaying that in Germany, following legalization in 2002, brothels were allowed to impose strict rules under their "right of direction," which included being at the brothel thirteen hours per day, abiding by the prices set by the brothel, and offering unprotected sex).

${ }^{220}$ Valisce, supra note 116 (explaining that following decriminalization in New Zealand, brothels set low prices for all-inclusive deals to remain competitive, which led to an overall decrease in prostitution prices as private and street workers had to follow suit); Chelsea Geddes, No, Decriminalisation of Johns and Pimps Has Not Improved Our Safety or Our Lives, Wahine ToA Rising (Apr. 23, 2020) (N.Z.), https://wahinetoarising.nz/survivor-stories/no-decriminalisation-of-johns-and-pimps-has-not-improved-oursafety-or-lives/ [https://perma.cc/8K47-5CXS] (stating that buyers "are expecting more and more, and willing to pay less and less"); How Legalizing Prostitution Has Failed, supra note 93 (reporting that in Germany, legalization led to a drop in prices, caused in part by an influx of women trafficked from Romania and Bulgaria); Cunningham \& Shah, supra note 145, at 1694 (finding that in Rhode Island, transaction prices for prostitution decreased about $33 \%$ during the four years that indoor prostitution was decriminalized).

${ }^{221}$ See supra note 33 and accompanying text; see also Prostitution Law Reform in New Zealand, supra note 73 (relaying a finding that most people who entered the sex trade did so for financial reasons). 
people in prostitution, such as specialized medical care, counseling, or housing, ${ }^{222}$ which might offset the negative effects of full decriminalization on prostitution prices.

Despite Germany's attempt to provide specific labor protections to people in prostitution, very few people in prostitution have used the legal framework that was created to enable contracts of prostitution employment, ${ }^{223}$ or to sue for wages. ${ }^{224}$ According to a social worker who has worked with people in prostitution for over two decades, working conditions have "worsened in recent years," and people in prostitution provide "significantly more services ... under riskier conditions and for less money than [in 2003]." ${ }^{225}$ Unlike the German law, the Gottfried-Salazar provides no specific labor protections that would account for the particular risks and harm associated with prostitution. ${ }^{226}$ It is therefore likely that the impacts of the bill would be just as bad, if not worse than in Germany.

Advocates of the Gottfried-Salazar bill expect general labor laws to sufficiently protect people in prostitution from problematic working conditions. ${ }^{227}$ If they are able to bring a lawsuit, people prostituted in brothels as independent contractors might succeed in being reclassified as "employees," if they can show that they are controlled by the brothels. ${ }^{228}$ However, it would likely take some time to develop such a lawsuit as it would

\footnotetext{
${ }^{222}$ See S. 3075, 2020-2021 Reg. Sess. (N.Y. 2020).

${ }^{223}$ See German Report on the Impact of the Prostitution Act, supra note 50, at 79. A survey found that only $1 \%$ of prostituted women had signed an employment contract. How Legalizing Prostitution Has Failed, supra note 93.

${ }^{224}$ Diu, supra note 71 (reporting that that only forty-four prostituted women had registered for benefits and that seemingly none had sued for payment).

${ }^{225}$ How Legalizing Prostitution Has Failed, supra note 93; see also GERMAN RePORT ON THE IMPACT OF THE Prostitution ACT, supra note 50, at 79 (finding in 2007 that the legalization of prostitution in Germany in 2002 did not have a "measurable, positive impact" on the working conditions of prostitution people in practice).

${ }^{226}$ See Sen., S3075, 2020-2021 Sess. (N.Y. 2020).

227 The Gottfried-Salazar bill does not provide for any special protections for people in prostitution. See id. The bill's sponsors aim to provide people in prostitution with better access to legal services, health care, and labor rights. See Press Release, DeCRIM NY, supra note 16 (quoting Assembly Member Gottfried).
}

${ }^{228}$ Brian Joseph, Nevada Brothel Faces Lawsuit Over Pay for Sex Workers, Las Vegas Rev. (Apr. 1, 2019), https://www.reviewjournal.com/local/local-nevada/nevada-brothel-faces-lawsuit-over-pay-for-sex-workers- 
require resources and named plaintiffs who are not afraid to lose their jobs. ${ }^{229}$ People in prostitution who are affected by discrimination, such as receiving less pay because of their race or other characteristic and being called racial slurs, could file a complaint with the Equal Employment Opportunity Commission (EEOC). ${ }^{230}$ In cases of extreme discrimination, the EEOC might bring a lawsuit against the brothel, as it has against a strip club. ${ }^{231}$ Considering the current stripping industry, it is unlikely that legal brothels would become unionized in New York $^{232}$ or provide adequate labor protections. ${ }^{233}$

1631233/ [https://perma.cc/LV9U-7FGA] (reporting on a class action brought against the Nevada brothel Sheri's Ranch asserting that they were wrongly classified as independent contractors); Records to be Released on Nevada Prostitute Employee Ruling, Kolo (Mar. 27, 2020),

https://www.kolotv.com/content/news/Records-to-be-released-on-Nevada-prostitute-employee-ruling569176721.html [https://perma.cc/32SU-5ZTH] (mentioning that the Department of Employment, Training and Rehabilitation determined that people prostituted in legal brothels are employees and not independent contractors).

${ }^{229}$ The lawsuit to reclassify brothel workers in Nevada as employees was only brought in 2019, even though prostitution brothels have been legal since the mid-nineteenth century. Jeff Hartman, History of Legalized Prostitution, World NeXT DooR, http://www.worldnextdoor.org/magazine/february-2014/history-oflegalized-prostitution/ [https://perma.cc/7JHF-B3K] (last visited Oct. 16, 2020) (bringing suit by two "former sex workers" who no longer worked in the brothel and were therefore not afraid to lose their jobs); see Joseph, supra note 228.

${ }^{230}$ See U.S. EQUAL EMP. OPPORTUNITY COMM’n, https://www.eeoc.gov [https://perma.cc/VYZ9-PAWQ] (last visited Oct. 16, 2020).

${ }^{231}$ See Papermoon Strip Club to Pay \$95,000 to Settle EEOC Race Discrimination Lawsuit, EEOC (Oct. 10, 2010), https://www.eeoc.gov/newsroom/papermoon-strip-club-pay-95000-settle-eeoc-race-discriminationlawsuit [https://perma.cc/6ZZ9-JQK] (reporting that the EEOC settled a lawsuit with a strip club where the managers used racial slurs against Black employees, forced them to work at the back of the club, and fired white employees who spoke up).

${ }^{232}$ The Lusty Lady Unionises, NSWP, https://www.nswp.org/timeline/event/the-lusty-lady-unionises [https://perma.cc/9MZL-XY5133J] (last visited Oct. 16, 2020) (stating that the only unionized adult entertainment business in the United States closed in 2013).

${ }^{233}$ Jenavieve Hatch, Left Out Of \#MeToo, Strippers Fight For More Rights In The Workplace, HufFington Post (Jan. 23, 2018), https://www.huffpost.com/entry/strippers-workplaceprotection_n_5a612ee8e4b074ce7a06e4e1 [https://perma.cc/SQ9A-FY6E] (describing the stripping industry as "plagued by ... a lack of workplace conditions; discrimination against dancers based on race or body or hair type; [and] arbitrary firings ..." and stating that the vast majority of strip clubs do not provide protections for dancers who are sick or injured, or in case of a family emergency). 
Further, women in the sex trade will certainly suffer many forms of sexual harassment, ${ }^{234}$ which are unlikely to be litigated. ${ }^{235}$ Moreover, prostitution necessarily implies sexual harassment against the people in prostitution under New York State law..$^{236}$

Decriminalizing the sex trade in New York would, in theory, allow for prostituted people to sign enforceable contracts of employment with brothels, and to be protected by labor laws. ${ }^{237}$ However, it is likely that brothel owners would begin by hiring them as independent contractors, and that the general labor laws currently in place would be insufficient to provide adequate "working conditions" to people in prostitution.

\section{Violence in the Sex Trade Would Remain Prevalent Under Full Decriminalization}

By decriminalizing prostitution, ${ }^{238}$ the Gottfried-Salazar bill would greatly reduce the policing of people in prostitution, including discriminatory policing against women of color and transgender women. ${ }^{239}$ The bill would likely reduce police violence against

\footnotetext{
${ }^{234}$ Bryce Covert, Strip Clubs Get Away With Exploiting Dancers Every Day, But These Strippers Are Fighting Back, THINK PROGRESS (Nov. 4, 2015), https://thinkprogress.org/strip-clubs-get-away-withexploiting-dancers-every-day-but-these-strippers-are-fighting-back-fb3a204bcc5a/ [https://perma.cc/4QRFNCD8] (recounting the experience of one woman who was routinely touched, hugged, kissed, grabbed, and slapped on the bottom by clients); Zachary Schwartz, Twenty Hours in a New York Strip Club, VICE (Mar. 3, 2015), https://www.vice.com/en/article/kwx3ey/twenty-hours-in-new-york-citys-raunchiest-strip-club-456 [https://perma.cc/LVZ5-AA2Z] (illustrating the prevalence of sexual harassment in strip clubs from bosses and clients).

235 The author found no successful sexual harassment cases brought against strip clubs.

${ }^{236}$ See N.Y.S. Div. OF Hum. RTS., SeXual Harassment Is Against the Law, https://dhr.ny.gov/sites/default/files/pdf/nysdhr-sexual-harassment.pdf [https://perma.cc/E4CK-CVJC] (last visited Oct. 16, 2020) (defining requests for sexual favors as a condition of employment, inappropriate physical contact, and conduct that creates "an intimidating, hostile or offensive working environment" as forms of sexual harassment).

${ }^{237}$ See Sen., S3075, 2020-2021 Sess. (N.Y. 2020), § A.10 (proposing to make pimping and operating a brothel legal).

${ }^{238}$ See N.Y. Sen. S3075 §§ A.1, A.18.

${ }^{239}$ See supra notes $39-40$ and accompanying text.
} 
people in prostitution, as the police would no longer be able to threaten to arrest them. ${ }^{240}$ This would hopefully lead to better relations between people in prostitution and the police. ${ }^{241}$

However, prostituted people would likely continue to experience high rates of violence, which would remain vastly underreported under decriminalization. ${ }^{242}$ When the sex trade is made legal and prostitution is considered a profession, violence against women in prostitution does not subside but is euphemistically referred to as "adverse experiences" 243 or "exploitative employment conditions." ${ }^{244}$ In legal brothels, pimps and others in positions of power are often extremely violent with the women who are prostituted. ${ }^{245}$ Decriminalizing pimping and making brothels legal in New York would therefore not greatly reduce the amount of violence suffered by prostituted people at the hands of pimps.

Violence against people in prostitution is most often perpetrated by prostitution buyers or men posing as clients. ${ }^{246}$ One survivor has observed that New Zealand brothels often fail to keep the women safe, and they rarely alert the police when violence occurs,

\footnotetext{
${ }^{240}$ Herrmann, supra note 23, at 105 (stating that some police officers coerce prostituted people to give them fellatio by threatening to arrest them); see also Maggie McNeill, Alaska Cops Fight for the Right to Sexually Exploit Prostitution Suspects, REASON (May 25, 2017), https://reason.com/2017/05/25/cops-fight-for-theright-to-sexually-exp/ [https://perma.cc/27QB-N52C] (listing many instances of police officers engaging in sexual acts with prostituted women, ranging from groping to intercourse, before arresting them).

${ }^{241}$ Gillian Abel et al., Univ. of Otago, The Impact of the Prostitution Reform Act on the Health and SAFETy PRActices OF SEX Workers 164 (2007) (relaying that many surveyed streetworkers described better relations with the police since decriminalization).
}

${ }^{242} I d$. at 119-20 (asserting that despite high rates of "adverse experiences," ranging from a client refusing to pay to being physically assaulted or raped by a client, most incidents are not reported to the police).

${ }^{243} \mathrm{Id}$. at 120 (explaining that "adverse experiences" include being robbed, assaulted, or raped by a client, being threatened with physical violence, and being held captive).

${ }^{244}$ PRA REPORT, supra note 108, at 168.

${ }^{245}$ See, e.g., Mathieson et al., supra note 25, at 385-86 (stating that in the Netherlands, pimps and bodyguards use extreme violence against women in legal brothels); see also Bindel, My Work as a Prostitute, supra note 114 (recounting an instance in which a receptionist in a legal brothel in New Zealand was yelling at a girl having a panic attack following an escort job - shaking, crying, unable to speak - and telling her to "get back to work").

${ }^{246}$ N.Z. PARLIAMENT, supra note 73. 
because it would be bad for business. ${ }^{247}$ Another survivor, who refers to the sex trade as "terrorism against women," denounces the violence in the New Zealand sex trade, accusing prostitution buyers of "shov[ing] bottles, cucumbers, carrots, stupidly oversized vibrators, shoe heels, batons, and whatever else ... so far and so hard up [the women's] vaginas that they damage their reproductive systems beyond repair." ${ }^{248}$ Full decriminalization does not put an end to such extreme violence.

Similarly, decriminalizing brothels and prostitution buyers in New York ${ }^{249}$ would likely not reduce the amount or the extent of violence that is perpetrated by prostitution buyers. Even though proponents of the Gottfried-Salazar bill claim that the objective of the bill is to keep people in the sex trade safe, ${ }^{250}$ the bill does not include any provisions to increase the safety of the sex trade or to reduce the violence committed against prostituted people.

For example, the Gottfried-Salazar bill does not require prostitution buyers to wear a condom. ${ }^{251}$ In New Zealand - where there is a specific condom use requirement — even though "every sex worker [has] a story related to a request for unsafe sex," charges against buyers for failing to use a condom are very rare, ${ }^{252}$ and the consequences of such a charge are limited. ${ }^{253}$ Considering that the Gottfried-Salazar bill does not even make

\footnotetext{
${ }^{247}$ Valisce, supra note 116 (relating that New Zealand brothels do not hire security guards or offer any protection).

${ }^{248}$ Sanchez, supra note 114 (quoting Ally-Marie Diamond).

${ }^{249}$ See S. 3075, 2020-2021 Reg. Sess. (N.Y. 2020), supra note 14, § A.10 (proposing to repeal sections 230.20 and 230.25 of the New York Penal Law).

${ }^{250}$ See Raven, supra note 7; Press Release, DECRIM NY, supra note 16.

${ }^{251}$ See S. S3075, 2020-2021 Sess. (N.Y. 2020).

${ }^{252}$ As of 2015, the safe-sex law had only been applied about seven times. Talia Shadwell, Man Charged with Failing to Use Condom with Prostitute, STUFF (Mar. 20, 2015) (N.Z.), https://www.stuff.co.nz/national/crime/67464897/man-charged-with-failing-to-use-condom-with-prostitute [https://perma.cc/3JH9-GC9D].

${ }^{253}$ Compare id. (reporting that a man who was charged under the law requiring safe "safer sex practices" was fined $\$ 400$ after admitting that he had removed the condom during sex without the woman's knowledge), with What You Need to Know About 'Stealthing', RNZ (May 23, 2017) (N.Z.), https://www.rnz.co.nz/news/the-wireless/374627/what-you-need-to-know-about-stealthing [https://perma.cc/DJ5N-ETYK] (indicating that non-consensual condom removal committed against a woman not in prostitution could be considered a form of sexual assault in New Zealand).
} 
condom use mandatory, it would likely be very difficult to bring complaints against buyers for non-consensual condom removal.

Further, unlike the New Zealand law, ${ }^{254}$ New York's decriminalization bill does not include a provision allowing a person in prostitution to refuse to have sex with someone who has paid. ${ }^{255}$ Absent a specific regulation pertaining to prostitution, contract law would create a legal obligation for someone who accepted payment in exchange for sex - or a job in a brothel - to submit to sex and to deliver the kind of sex that the prostitution buyer wants. ${ }^{256}$ While it is highly unlikely that a court would force a person to perform a contracted-for sexual act, a prostitution buyer could reasonably argue that he does not have to pay for a performance that does not fully satisfy the contract. ${ }^{257}$

The full decriminalization of the sex trade is unlikely to put an end to the murders of prostituted women in the United States. ${ }^{258}$ In New Zealand, several prostituted women have been murdered by prostitution buyers. ${ }^{259}$ Women who are prostituted in the street

\footnotetext{
254 The PRA provides that "nobody . . can force a sex worker to have sex, even if a client has paid.” N.Z. Prostitutes' Collective, supra note 193.
}

${ }^{255}$ See S. 3075, 2020-2021 Sess. (N.Y. 2020).

${ }^{256}$ See ReSTATEMENT (SECOND) OF CONTRACTS $§ 1$ (AM. L. InST. 1981) (defining a contract as "a promise or a set of promises for the breach of which the law gives a remedy, or the performance of which the law in some way recognizes as a duty").

${ }^{257}$ See Katie O'Reilly, When Parents and Surrogates Disagree on Abortion, AtLAnTiC (Feb. 18, 2016), https://www.theatlantic.com/health/archive/2016/02/surrogacy-contract-melissa-cook/463323/ (stating that "the vast majority" of surrogacy contracts include a clause allowing the intended parents to make decisions about abortion and that, while courts would not force a surrogate to undergo an abortion, she might not have a right to the payment stipulated in the contract if she were to violate such a clause).

258 See John J. Potterat, Mortality in a Long-Term Open Cohort of Prostitute Women, AM. J. EPIDEMIOLOGY, Apr. 2004, at 778, 783 (finding the workplace homicide rate for prostituted women of 204 for 100,000 to be many times higher than the highest rates for other professions, such as 4 per 100,000 for female liquor store workers and 29 per 100,000 for male taxicab drivers); see also Silja J.A. Talvi, The Truth About the Green River Killer, ALTERNet (Nov. 12, 2003), https://www.alternet.org/2003/11/the_truth_about_the_green_river_killer/[https://perma.cc/XDF9-WLEJ] (reporting on the arrest of a serial killer who admitted to murdering prostituted women because he hated prostitutes and knew they would not be reported missing immediately).

${ }^{259}$ Ngatai Lynette Manning was picked up by a man posing as a buyer and violently murdered by a gang. Anna Louise Wilson was raped and murdered in December 2005 by a prostitution buyer after refusing unprotected sex. Suzie Sutherland was strangled by a prostitution buyer in April 2005. Penny White, 
are considered an at-risk population. ${ }^{260}$ In comparison, Sweden, a country with twice the population of New Zealand, has seen no murders of prostituted women by a pimp or a prostitution buyer since the partial decriminalization of prostitution in $1999 .{ }^{261}$ Sweden's legislative model has been more successful at leveling the balance of power between prostituted people and buyers. $^{262}$

The Gottfried-Salazar bill does nothing to address the violence perpetrated by pimps and buyers ${ }^{263}$ that is inherent to the sex trade. ${ }^{264}$ Decriminalization of all aspects of the sex trade would exacerbate the imbalance of power between prostitution buyers and prostituted people, ${ }^{265}$ and would sanction the power and control that pimps have over prostituted people. ${ }^{266}$ The bill does not provide for any control mechanisms, such as

Remembering the Murdered Women Erased by the Pro-Sex Work Agenda, Feminist CurRent (Nov. 3, 2015) (Can.), https://www.feministcurrent.com/2015/11/03/remembering-the-murdered-women-erased-by-the-prosex-work-agenda/ [https://perma.cc/MQ9N-PBKD]. More recently, Renee Duckmanton was killed on May 14, 2016. Sam Sherwood, Inside the Brutal and Disturbing Murder of Renee Duckmanton, STUFF (Feb. 23, 2018) (N.Z.), https://www.stuff.co.nz/national/crime/101696753/inside-the-brutal-and-disturbing-murder-ofrenee-duckmanton [https://perma.cc/4AMR-57PM].

${ }^{260}$ Sherwood, supra note 259.

${ }^{261}$ White, supra note 259.

${ }^{262}$ See Meghan Murphy, Being and Being Bought: An Interview with Kajsa Ekis Ekman, Feminist CuRRENT (Jan. 20, 2014) (Can.), https://www.feministcurrent.com/2014/01/20/being-and-being-bought-an-interviewwith-kajsa-ekis-ekman/ [https://perma.cc/9ZKD-375D] (stating that partial decriminalization gives prostituted people more power).

${ }^{263}$ See supra notes $245-246$ and accompanying text.

${ }^{264}$ People in prostitution face high rates of violence under both criminalization and decriminalization regimes. See Farley et al., supra note 35, at 33-34 (finding that out of 854 people interviewed who were in prostitution in nine countries, $71 \%$ were physically assaulted in prostitution, $63 \%$ were raped, and $68 \%$ met the criteria for PTSD).

${ }^{265}$ Prostitution is inherently unequal, as one person holds the money that the other needs. See Carter \& Giobbe, supra note 59, at 51. Decriminalizing both actors does not modify this socio-economic imbalance of power, but it does empower the prostitution buyer to demand sexual access on his own terms without fear of being arrested.

${ }^{266}$ See supra notes $212-216$ and accompanying text. 
mandatory brothel inspections, and it does not ban any particularly violent practices. ${ }^{267} \mathrm{It}$ is very likely that violence would remain prevalent under the decriminalization regime that is proposed by the Gottfried-Salazar bill.

\section{The Increase of Prostitution and Sex Trafficking}

\section{Full Decriminalization Would Increase the Size of the Sex Trade}

The decriminalization of the sex trade in New York would most likely lead to an increase in prostitution, as it did in the Netherlands, Germany, and Rhode Island. ${ }^{268}$ The United States sex trade is already estimated to be one of the largest in the world. ${ }^{269} \mathrm{New}$ York City, and Queens in particular, has a booming sex industry. ${ }^{270}$ The growth of the sex trade in New York State would likely occur primarily in the largest cities, particularly New York City. ${ }^{271}$ Many of the existing illicit massage parlors and other hidden sex establishments would become legal brothels. ${ }^{272}$

\footnotetext{
${ }^{267}$ See, e.g., Germany Introduces Unpopular Prostitution Law, supra note 102 (stating that Germany passed a new law relating to prostitution in 2017, banning certain abusive practices such as flat-rate brothels and gang-bangs).

${ }^{268}$ See supra notes 78, 94-97 and accompanying text; Cunningham \& Shah, supra note 145, at 1694 (finding that following the unintentional decriminalization of the indoor sex trade in Rhode Island, the size of the indoor sex trade increased, including erotic massage provision which increased by over $200 \%$ ).

${ }^{269}$ See How Many Prostitutes Are in the United States and the Rest of the World?, ProCon (Jan. 11, 2018), https://prostitution.procon.org/view.answers.php?questionID=000095 [https://perma.cc/YP9Z-6FXX] (reporting that there are an estimated one to two million prostituted people in the United States).

${ }^{270}$ See Sara Dorn \& Brad Hamilton, Inside Queens' Hidden Sex District, N.Y. Post (Feb. 2, 2019), https://nypost.com/2019/02/02/inside-queens-hidden-sex-district/ [https://perma.cc/W37W-YR8E].

${ }^{271}$ See Cunningham \& Shah, supra note 145, at 1688, 90 (stating that following the decriminalization of indoor prostitution in Rhode Island, the main newspaper advertising prostitution contained advertisements for massage parlors in Providence - the most populous city in the state - and surrounding areas, and that erotic massage increased in Providence according to anecdotal evidence); supra note 110 and accompanying text (relating to the apparent growth of street prostitution in Auckland).

${ }^{272}$ In New Zealand, massage parlors were renamed brothels and gentleman's clubs. See Valisce, supra note 116.
} 
Making brothels and prostitution buying legal normalizes prostitution buying ${ }^{273}$ and gives people the illusion that prostitution must be safe and consensual, as long as it is legal. ${ }^{274}$ This naturally leads more men to purchase sex. ${ }^{275}$ Therefore, by making prostitution buying and brothels legal, the state would be giving men the right to purchase access to the bodies of women who are in financial need and implicitly sanctioning the behavior of the buyers and pimps.

In the same way that Germany and Amsterdam have become sex tourism centers in Europe, ${ }^{276}$ New York State would become an American sex tourism destination. New York City is one of the world's top tourist destinations, attracting over fourteen million international visitors in 2019. ${ }^{277}$ Additionally, men from surrounding states might prefer to come to New York for prostitution if it is made legal only in the state of New York. ${ }^{278}$

273 Jimmy Carter, To Curb Prostitution, Punish Those Who Buy Sex Rather than Those Who Sell It, WASH. Post (May 31, 2016), https://www.washingtonpost.com/opinions/to-curb-prostitution-punish-those-who-buysex-rather-than-those-who-sell-it/2016/05/31/e0376adc-236d-11e6-aa84-42391ba52c91_story.html [https://perma.cc/WV37-UP7E].

${ }^{274}$ Gabrielle Fonrouge, Sex-trade Survivor: Don't Legalize Prostitution in New York, N.Y. Post (June 2 , 2019), https://nypost.com/2019/06/02/former-sex-worker-dont-legalize-prostitution-in-new-york/ [https://perma.cc/8PTF-3SPJ].

275 See EKBERG, supra note 66, at 36 (citing various studies that have concluded that the majority of prostitution buyers consider that prohibiting the purchase of prostitution sex is one of the most effective deterrents).

276 See Louise Barnett, Germany a 'Sex Tourism Hotspot', TEL. (Nov. 15, 2013), https://www.telegraph.co.uk/news/worldnews/europe/germany/10452246/Germany-a-sex-tourismhotspot.html [https://perma.cc/9X49-XTYW] (stating that Germany has become a "sex-tourism hotspot"); Bindel, The Pimping of Prostitution, supra note 115, at 104 (relating that a 2009 study on sex buyers in the UK found that $49 \%$ of the 103 men interviewed had bought prostitution outside the UK, the most popular destination being Amsterdam); Dear Foreigners: Please Don't Visit Amsterdam Until You've Read These 5 Facts, EXPATICA, https:/www.expatica.com/nl/amsterdam/basics-amsterdam/dear-foreigners-please-dontvisit-amsterdam-until-youve-read-these-5-facts-740171/ [https://perma.cc/6CWX-VSA6] (last updated Jan. 23,2020 ) (stating that sex tourism in the Netherlands brings in one billion dollars per year).

${ }^{277}$ Francesca Street, The Most Visited Cities in the World 2019, CNN (Dec. 3, 2019), https://www.cnn.com/travel/article/most-visited-cities-euromonitor-2019/index.html [https://perma.cc/D2MN-JPA6].

${ }^{278}$ See, e.g., Bindel, The Red Light District of Amsterdam, supra note 78 (relating that many British men who purchase sex say that they would never do so in their home country, but felt they had permission to do it in Holland). 
Sex tourism would thrive in New York City under full decriminalization, and brothels would become some of the city's tourist attractions. ${ }^{279}$

\section{Legitimizing the Sex Trade Would Lead to an Increase in Involuntary Prostitution}

Various reports, studies, and investigations have shown that making the sex trade legal in Germany and the Netherlands led to an increase in or continuation of human trafficking. ${ }^{280}$ Firstly, large numbers of women are trafficked in legal brothels. ${ }^{281}$ Secondly, the decriminalization of brothels led to a "major increase in unlicensed, invisible prostitution," ${ }^{, 282}$ which is also linked to human trafficking. ${ }^{283}$ Full decriminalization of the sex trade in New York would likely lead to the exploitation of many survivors of trafficking in both legal and illegal prostitution venues. ${ }^{284}$

While those in favor of full decriminalization claim that there is a clear distinction between forced and voluntary prostitution, ${ }^{285}$ the line is often not so clear. ${ }^{286}$ Many people

\footnotetext{
279 See supra note 276 and accompanying text. Legal brothels would likely become a part of the adult entertainment industry in New York City. See Alison Kotch, The Best Strip Clubs in NYC, TimeOut (July 14, 2016), https://www.timeout.com/newyork/sex-dating/best-strip-clubs [https://perma.cc/4B65-935N].
}

${ }^{280}$ See supra note 93 and accompanying text; see also Dutch POLICE REPORT, supra note 84, at 10-20 (finding that trafficking in licensed window brothels took place "almost unimpeded").

${ }^{281}$ See Dutch POLICE RePORT, supra note 84 , at 84 (finding that $50 \%$ to $90 \%$ of those who were prostituted in legal brothels in the Netherlands had been trafficked); Amsterdam Buys Red-light Brothels, EXPATICA (Sept. 21, 2007), https://www.expatica.com/nl/uncategorized/amsterdam-buys-red-light-brothels-33803/ [https://perma.cc/7RX8-DQ93] (citing then-mayor Job Cohen who justified closing one third of Amsterdam's red-light district by stating that the Dutch law "was created for voluntary prostitution but these days we see trafficking of women, exploitation and all kinds of criminal activity"); RAAD VAN STATE, supra note 80 (stating that a court found that there was "a reasonable chance" that trafficking victims would work in the Utrecht window brothels).

${ }^{282}$ Boztas, supra note 81 (citing Amsterdam Mayor Femke Halsema).

${ }^{283}$ Amsterdam's Mayor: 'Prostitutes Should Not Be a Tourist Attraction', supra note 204.

${ }^{284}$ See supra notes $280-283$ and accompanying text.

${ }^{285}$ See supra note 49 and accompanying text.

${ }^{286}$ See Tansy Breshears, Stigma Against Sex Workers Must End, Root (Dec. 20, 2017), https://www.theroot.com/stigma-against-sex-workers-must-end-1821475064 [https://perma.cc/4CHK-TKCZ] (stating that there often is no clear line between "victim of sexual exploitation" and "survival sex worker"). 
end up in prostitution due to various forms of structural oppression and the lack of statefunded services ${ }^{287}$ without a trafficker necessarily being involved ${ }^{288}$ Even though there are large amounts of involuntary prostitution in countries that have legalized the sex trade, governments generally do not focus on developing exit services. ${ }^{289}$ In New Zealand, for example, the NZPC does not offer exit services. ${ }^{290}$ Instead, the organization hands out information about how to avoid "burn-out syndrome," which, according to one sex trade survivor, is an inaccurate term for what is actually "a normal response to ongoing sexual abuse."291

Unsurprisingly, the Gottfried-Salazar bill includes absolutely no mention of exit options or services. ${ }^{292}$ It is solely focused on decriminalizing prostituted people, pimps, and prostitution buyers, clearing past criminal convictions, and making brothels legal. ${ }^{293}$ The Gottfried-Salazar bill's proposed regime would enable pimps, prostitution buyers, and structural inequalities to continue to coerce more vulnerable people into prostitution,

\footnotetext{
${ }^{287}$ See Carter \& Giobbe, supra note 59, at 43 (arguing that "culturally supported tactics of power and control [which include economic marginalization] facilitate the recruitment or coercion of women and children into prostitution and effectively impede their escape").

${ }^{288}$ See supra note 33 and accompanying text.

${ }^{289}$ Bindel, The Pimping of Prostitution, supra note 115, at 117; see also DAALDER, supra note 82 (relating that seven years after legalization in the Netherlands, only $6 \%$ of municipalities offered options for exiting prostitution).

${ }^{290}$ The NZPC's website only states that a person wishing to leave prostitution can receive work and income benefits. N.Z. ProstituteS' Collective, supra note 193, https://www.nzpc.org.nz/ [https://perma.cc/72VUVAHB]. Sabrinna Valisce, who volunteered for the NZPC when she was in prostitution, recounts that she was "absolutely ignored" when she asked the Wellington office if they were working on exit services. See Bindel, My Work as a Prostitute, supra note 114.

${ }^{291}$ Bindel, The Pimping of Prostitution, supra note 115, at 102.

292 See S. S3075, 2020-2021 Sess. (N.Y. 2020).

${ }^{293}$ See id.
} 
particularly immigrant women, ${ }^{294}$ Indigenous women, ${ }^{295}$ other women of color, ${ }^{296}$ and transgender women. ${ }^{297}$

\section{Full Decriminalization Would Make It Harder to Identify and Prosecute Trafficking}

If the New York sex trade is fully decriminalized, it will likely become more difficult to prosecute trafficking cases. Firstly, legal frameworks relating to the sex trade do not successfully facilitate the identification of human trafficking by the authorities. ${ }^{298}$ Relevant actors - such as brothel owners, prostitution buyers, victims, the police, and prosecutors - might lack incentives to report trafficking. ${ }^{299}$ The regulation of brothels does not ensure an absence of exploitation, particularly by third-party pimps. ${ }^{300}$

Secondly, empirical data suggest that when the sex trade is entirely legal, it is harder for authorities to investigate trafficking. ${ }^{301}$ When brothels are simply decriminalized without any regulation, the police may require a search warrant to even enter a brothel. ${ }^{302}$

\footnotetext{
${ }^{294}$ See, e.g., Barnett, supra note 276 (stating that $95 \%$ of prostituted women in Germany are foreign nationals).

${ }^{295}$ See, e.g., Sanchez, supra note 114.

${ }^{296}$ See id.; supra note 39.

${ }^{297}$ See supra note 39.

${ }^{298}$ DutCh POLICE RePORT, supra note 84, at 100.

${ }^{299}$ See supra note 88 and accompanying text.

${ }^{300}$ See supra note 87 and accompanying text.

${ }^{301}$ See Dutch Police Report, supra note 84, at 104-10 (positing that under legalization in the Netherlands, relevant actors lack incentives to report or prosecute trafficking); How Legalizing Prostitution Has Failed, supra note 93 (reporting that according to Munich's Police Chief, the German law makes it very difficult for police to investigate human trafficking).
}

302 New South Wales Legis. Council, Human Trafficking in New South Wales 50 (2017) (Austl.) (finding that in New South Wales, where the sex trade is completely decriminalized and unregulated, the police are unable to enter a brothel without a search warrant, making it impossible for the police to check what is going on inside the brothels). 
Further, the police may choose not to investigate legal brothels. ${ }^{303}$ Under the GottfriedSalazar bill, the police would have no obligation to investigate brothels. ${ }^{304} \mathrm{~A}$ brothel licensing system, which is not even considered in the bill, ${ }^{305}$ might provide the police with access to brothels, but it would not ensure that they would be able to successfully identify trafficking victims in the legal brothels.

Finally, decriminalizing pimps and brothels makes it more difficult to prosecute trafficking. ${ }^{306}$ Under current New York law, the varying offenses and penalties for promoting prostitution allow prosecutors to offer plea deals and to exercise discretion in charging traffickers with lower offenses that are much easier to prove. ${ }^{307}$ Following the Gottfried-Salazar bill, prosecutors would have to prove either "sex trafficking" or the promotion of prostitution through "force or intimidation" in order to secure a conviction against a pimp or brothel owner when the victim is not a child. ${ }^{308}$ Due to the difficulty of securing such a conviction, police and prosecutors may prefer to prioritize other cases. ${ }^{309}$

\footnotetext{
${ }^{303}$ See Bindel, The Pimping of Prostitution, supra note 115, at 102 (relating that according to an investigator in New Zealand, police are not required to investigate what happens in brothels because they are not illegal, which allows organized crime to permeate the indoor sex trade); Nick McKenzie et al., Legal Brothels Linked to International Sex Trafficking Rings, Sydney MoRning Herald (Oct. 10, 2011) (Austl.), https://www.smh.com.au/national/legal-brothels-linked-to-international-sex-trafficking-rings-201110091lfxs.html [https://perma.cc/5Z7Y-URMU] (reporting that senior state police sources from Australia admitted that "the policing of organised crime in the legal brothel sector is patchy and the regulation of brothels ... has been woeful").
}

${ }^{304}$ See S. 3075, 2020-2021 Sess. (N.Y. 2020).

${ }^{305}$ See id.

${ }^{306}$ See, e.g., Olivia Carville, Exposed: The Dark Underbelly of Human Trafficking in New Zealand, N.Z. HERALD (Sept. 22, 2016), https://www.nzherald.co.nz/nz/news/article.cfm?c id=1\&objectid=11711211 [https://perma.cc/SAY6-GYYY] (stating that in New Zealand, even though people are trafficked for purposes of prostitution, the government did not secure a single human trafficking conviction until 2016).

307 Compare N.Y. Penal Law $\S 230.20$ (McKinney 2019), with N.Y. Penal Law $§ 230.30$ (McKinney 2019) (stating that a conviction for promoting prostitution in the fourth degree requires a showing that a defendant knowingly caused another person to engage in prostitution, or profited from it; a conviction for promoting the prostitution of an adult in the second degree requires proof that the prostituted person was compelled to engage in prostitution by force or intimidation).

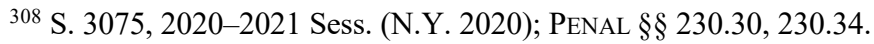

${ }^{309}$ See supra note 301 and accompanying text. 
The decriminalization bill proposes to change the requisite mens rea associated with "advancing prostitution" from a knowledge requirement to one of intent. ${ }^{310}$ This would make it harder to prove that a pimp advanced the prostitution of another person, in turn making it more difficult to obtain a conviction for any level of promoting or compelling prostitution. ${ }^{311}$ Furthermore, the bill suggests an exception to the definition of "advancing prostitution," by which a person under the age of twenty-one cannot advance the prostitution of a person who is seventeen or older without actively participating in "compulsion by force or intimidation or in sex trafficking." 312 This might make it harder to address the rather common cases of minors or very young adults pimping out their friends and girlfriends. ${ }^{313}$

The Gottfried-Salazar bill is unlikely to accomplish its goals of limiting the underground sex trade, reducing the harm that is caused in prostitution, and better enforcing laws against human trafficking. ${ }^{314}$ New York should therefore adopt the Equality Model, a progressive solution that gives more power to people in prostitution and less to their abusers, instead.

\footnotetext{
310 See N.Y. S. S3075 § A.1; PENAL § 230.15-33.

${ }^{311}$ Under the current prostitution laws, promoting prostitution in the first, second, third, or fourth degree, and compelling prostitution, require the perpetrator to knowingly advance prostitution. PENAL $\S \S 230.20-33$.
}

${ }^{312}$ N.Y. S. S3075 § A.1.

${ }^{313}$ A study on the prevalence of the commercial sexual exploitation of children in New York state found that $22 \%$ of trafficked minors from upstate New York who were surveyed were trafficked by a minor friend or acquaintance. Frances Gragg et al., Westat, New York Prevalence Study of Commercially SEXUALLy EXPLOITED CHILDREN 38 (2007). According to interviews with 185 homeless youth in New York City, 27\% of those who were trafficked for sexual exploitation were trafficked by boyfriends. JAYNE Bigelsen \& Stefanie Vuotto, Covenant House, Homelessness, Survival SeX and Human TRAfFicking: As Experienced by the Youth of Covenant House New York 10 (2013). Further, a significant proportion of pimps begin trafficking and prostituting people before they turn eighteen. RAPHAEL et al., What We Know About Sex Trafficking, Prostitution, and Sexual Exploitation in the U.S. 24 (2017).

${ }^{314}$ See Press Release, DECRIM NY, supra note 16. 


\section{Dismantling the System of Prostitution Exploitation through the Equality Model and Transformative Justice}

In order to better protect the rights and lives of prostituted people, ${ }^{315}$ New York State should not further entrench the system of prostitution by decriminalizing the entire sex trade. It should, instead, aim to dismantle this system of exploitation while protecting those who are exploited. This Part advocates for an expansive version of the Equality Model that relies on principles of reparative ${ }^{316}$ and transformative justice. ${ }^{317}$ Section A argues that the New York legislature should decriminalize people in prostitution while finding innovative ways to hold buyers, pimps, and traffickers accountable. Section B reasons that reparative justice and the provision of services are essential to center the needs of survivors and people in prostitution. Finally, Section C discusses how New York should address the root causes of the system of prostitution, particularly through education and a social safety net.

\footnotetext{
315 According to its sponsors, the Gottfried-Salazar bill seeks to "keep sex workers safe and empower sex workers in their workplaces," to "empow[er] sex workers to report violence against them," to give sex workers "better access to legal assistance, health care, and rights," and "to enforce laws against human trafficking and sex with minors." Id.

${ }^{316}$ Reparative justice is "the idea that victims of wrongdoing or injustice are entitled to some form of repair." Joseph Frigault, Reparations for Historic Injustice, 1000-WORD PHILOSOPHY (May 8, 2019), https://1000wordphilosophy.com/2019/05/08/reparations-for-historic-injustice/\#_ftnref1 [https://perma.cc/NAR4-8RQV].

${ }^{317}$ About TJC, Transformative Just. COALITION, https://tjcoalition.org/about-tjc/ [https://perma.cc/LX9FAS3R] (explaining that transformative justice seeks to "bring about justice and equality" through "transformative institutional changes"); Transformative Justice, TRANSFORMHARM.ORG, https://transformharm.org/transformative-justice/ [https://perma.cc/Q2KE-HGRL] (stating that a core belief of transformative justice is that " $[\mathrm{t}] \mathrm{he}$ conditions that allow violence to occur must be transformed in order to achieve justice in individual instances of violence").
} 


\section{A. Recognizing Prostitution as a System of Oppression of Prostituted People}

\section{Decriminalizing Prostitution}

People in prostitution should not be criminalized. ${ }^{318}$ Rather, they should be recognized as survivors of commercial sexual exploitation. ${ }^{319}$ The New York legislature should therefore repeal the criminalization of prostitution in section 230.00 of the Penal Law, ${ }^{320}$ as the Gottfried-Salazar bill proposes. ${ }^{321}$ In addition to what the bill suggests, ${ }^{322}$ New York should not criminalize prostitution in a school zone, because in many cases, prostituted women do not choose to be in prostitution and should never be penalized. ${ }^{323}$ Section $230.03^{324}$ should therefore also be repealed, and the definition of "school zone" should be moved to section 230.08 . $^{325}$ When decriminalizing prostitution, the legislature should also provide for the vacatur of prior criminal convictions under the repealed offenses, as the Gottfried-Salazar bill proposes. ${ }^{326}$

\footnotetext{
${ }^{318}$ See supra notes $45-47$ and accompanying text.

${ }^{319}$ People in prostitution would therefore be considered crime victims. For a critique of how the neoliberal order makes it taboo to talk about victims by falsely characterizing victimhood as a characteristic of weakness and passivity, which legitimizes class divisions and gender inequality, see EKMAN, supra note 120, at 26-27.
}

${ }^{320}$ N.Y. Penal Law $§ 230.00$ (McKinney 2019).

${ }^{321}$ The bill proposes to amend section 230.00 to delete the language criminalizing prostitution and to add the definitions relevant to article 230. S. S3075, 2020-2021 Sess. (N.Y. 2020) § A.1.

${ }^{322}$ See N.Y. S. S3075 § A.4.

${ }^{323}$ See supra notes $31-35$ and accompanying text.

${ }^{324}$ Penal $§ 230.03$.

${ }^{325} I d$. $\S 230.08$ (patronizing a person for prostitution in a school zone).

${ }^{326}$ S. S3075, 2020-2021 Sess. (N.Y. 2020) pt. B; see also Hatcher et al., supra note 12, at 2 (explaining that "[v]acatur laws are essential to undo injustices that many survivors face when they are branded as criminals, rather than as victims of crime"). The Gottfried-Salazar bill also seeks to provide for the elimination of prior convictions for patronizing a person for prostitution and for promoting prostitution in the third or fourth degree, which this Note does not support, as it advocates for penalizing pimps and prostitution buyers. 


\section{Holding Prostitution Buyers Accountable for Their Role in the System of Prostitution}

The Gottfried-Salazar bill seeks to decriminalize "patronizing a person for prostitution," as long as the prostitution buyer has no reason to believe that the person being bought is under eighteen. ${ }^{327}$ Repealing this offense would make it legal for a man to take advantage of a woman's lack of financial resources or other vulnerability to obtain sexual access to her.

The New York legislature should not condone the coercion of sexual access through money. Instead, the state should continue to hold prostitution buyers accountable for their role in the system of prostitution. In addition to decriminalizing people in prostitution, New York should recognize that prostitution is not a "victimless crime," but a form of abuse committed by the prostitution buyer against the person he buys for sex. ${ }^{328}$ To better reflect the exploitative role that prostitution buyers play in the system of prostitution, legislators should consider renaming "patronizing a person for prostitution" to "commercial sexual exploitation of an adult" and "aggravated patronizing a minor for prostitution" to "commercial sexual exploitation of a minor." Washington State similarly changed "patronizing a juvenile prostitute" to "commercial sexual abuse of a minor" in $2007,{ }^{329}$ and the Seattle City Council renamed "patronizing a prostitute" to "sexual exploitation" in $2015 .{ }^{330}$

The Equality Model has the effect of readjusting the unequal relationship between the prostitution buyer and the prostituted person. If the buyer treats a prostituted woman badly or refuses to pay, she can threaten to report him for commercial sexual exploitation. ${ }^{331} \mathrm{He}$ cannot threaten to report her because she has not done anything

\footnotetext{
${ }^{327}$ See S. S3075 § A.5.

${ }^{328}$ In an open letter to her "sex customers," Danish prostitution survivor Tanja Rahm described the role that buyers have in the prostitution system and how they exploit the people in prostitution. Miranda Yardley, Letter from Sex Trade Survivor Tanja Rahm to all her Johns, MIRANDA YARDLEY (Jan. 22, 2014), https://mirandayardley.com/en/letter-from-sex-trade-survivor-tanja-rahm-to-all/ [https://perma.cc/CU6H5RNS].

${ }^{329}$ Mathieson et al., supra note 25, at 412.

${ }^{330} I d$. at 414 .

${ }^{331}$ Murphy, supra note 262.
} 
illegal. ${ }^{332}$ The penalization of prostitution buyers, coupled with the decriminalization of people in prostitution, deters men from purchasing or attempting to purchase prostitution sex, ${ }^{333}$ modifies the behavior of men who purchase prostitution, and changes the general public's attitude towards commercial sexual exploitation. ${ }^{334}$

Historically, prostitution buyers have been greatly under-policed and treated with considerable empathy by judges and society. ${ }^{335}$ Instead of decriminalizing their behavior, legislators should consider whether there are viable alternatives to incarceration that would curb the demand for prostitution and provide sufficient protection for people in prostitution. Many countries and U.S. states have implemented educational programs for prostitution buyers as either an alternative to prosecution or as a sentence. ${ }^{336}$ Although it is difficult to measure how successful these programs have been in curbing the demand for prostitution, ${ }^{337}$ they afford survivors an opportunity to confront their abusers and have their voices heard. ${ }^{338}$ They also give the men who are arrested an opportunity to see survivors as equal human beings, and to better understand what they went through. ${ }^{339}$

${ }^{332} I d$.

${ }^{333}$ See supra note 275.

${ }^{334}$ EKBERG, supra note 66, at 10.

${ }^{335}$ See Lefler, supra note 42, at 14-15 (explaining that men were not blamed for buying prostitution as they were viewed as having uncontrollable sexual desires, and that, unlike prostituted women, they were considered "reformable" despite having committed "an immoral sexual act").

${ }^{336}$ See supra Sections I.B.2, I.C.1.

${ }^{337}$ Although one study found that the first American john school, established in San Francisco, was successful at reducing recidivism of offenders, other studies have shown low recidivism rates overall amongst men arrested for prostitution, regardless of whether they attended a program or not. Cynthia Castaldo-Walsh, How Effective Are John Schools?, Not EnOugH Good (June 24, 2011), https://notenoughgood.com/2011/06/effectiveness-of-john-schools/ [https://perma.cc/HC4B-QBL2].

${ }^{338}$ For example, in one of France's first john school programs, a nineteen-year-old survivor told the men that she had no dignity in prostitution, and that each encounter with a buyer was rape. See Louise Colcombet, Stage de sensibilisation: non, la prostitution n'est pas une partie de Plaisir [Prostitution: No, Prostitution Is Not a Fun Time], Le PARISIEN (Jan. 8, 2018) (Fr.), http://www.leparisien.fr/faits-divers/stage-desensibilisation-non-la-prostitution-n-est-pas-une-partie-de-plaisir-28-01-2018-7527864.php [https://perma.cc/G9H2-RU2J].

339 One of the participants stated that hearing from the survivor made him think about his actions. Id. In a different session, one of the participants said that he had not realized how violent prostitution was for the 


\section{Maintaining the Penalization of Brothels and Pimping}

A full decriminalization regime benefits prostitution buyers, pimps, and traffickers, rather than the people exploited in prostitution. ${ }^{340}$ If brothels and pimping were to become legal, sex tourism and commercial sexual exploitation would thrive, ${ }^{341}$ violence would remain prevalent throughout the sex trade, ${ }^{342}$ and the system of prostitution would be strengthened. Therefore, the New York legislature should not enact the provisions of the Gottfried-Salazar bill which aim to decriminalize pimping and brothels.

The bill modifies the definition of "advancing prostitution" and increases the level of mens rea for promoting or compelling prostitution. ${ }^{343}$ These proposed modifications would make the prosecution of pimps and traffickers overly difficult ${ }^{344}$ and should therefore not be enacted. The offense of promoting prostitution in the fourth degree should not be repealed, because doing so would make pimping and advertising prostitution legal, which would only contribute to the growth of the sex trade. ${ }^{345}$ Decriminalizing "promoting prostitution in the fourth degree" would also make it harder to prosecute cases of commercial sexual exploitation. In addition, prosecutors would no longer be able to offer a prostitution-related misdemeanor conviction to first-time offenders or to pursue a misdemeanor conviction for promoting prostitution. ${ }^{346}$ Section 230.25 of the penal law, ${ }^{347}$ which prohibits brothels and sex tourism businesses, should

women. Alice Moreno, Prostitution: comment se déroulent les stages de sensibilisation des clients [Prostitution: How Do the Awareness Trainings for Clients Operate?], RTL (Apr. 8, 2019) (Fr.), https://www.rtl.fr/actu/debats-societe/prostitution-comment-se-deroulent-les-stages-de-sensibilisation-desclients-7797385566 [https://perma.cc/SRR4-TA6N].

${ }^{340}$ See supra Section II.B.2.

341 See supra Section II.C.

${ }^{342}$ See supra Section II.B.3.

${ }^{343}$ S. 3075, 2020-2021 Reg. Sess. (N.Y. 2020), supra note 14, § A.1.5.(a); N.Y. PeNAL LAW $\S \S 230.15-33$ (McKinney 2019).

${ }^{344}$ See supra Section II.C.3.

345 See supra note 268; PENAL $\S 230.20$.

346 "Promoting prostitution in the fourth degree" is the only pimping offense that is not a felony under New York law. Id. § 230.20.

${ }^{347} I d . \S 230.25$. 
also remain in effect to prevent the growth of sex tourism, brothels, and sexual exploitation. ${ }^{348}$

Decrim NY claims that the Gottfried-Salazar bill ends the criminalization of "consenting adults who ... collaborate with or support sex working peers." ${ }^{\text {"34 }}$ However, the decriminalization of pimps and brothels is not necessary to allow people in prostitution to work together for safety. Rather, the legislature should adopt an affirmative defense to the charge of promoting prostitution in the third or fourth degree. This amendment could read as follows:

In any prosecution under section 230.20 or section 230.25 of this part, it is an affirmative defense that the defendant engaged in the conduct to provide safety to a person engaging in prostitution and did not gain a financial benefit from the transaction.

While there is a slight risk that some exploitative pimps might abuse such an affirmative defense, it would ensure that a person could not be convicted of promoting prostitution simply for helping a person who is engaging in prostitution. Peers who are engaging in prostitution together for safety reasons would also be covered by this affirmative defense.

In seeking to address pimping and trafficking in innovative ways, New York could be the first state to repurpose the HTICs as specialized courts for pimps and traffickers. Today, states use problem-solving human trafficking courts to identify and assist commercially sexually-exploited children or adults who are survivors of human trafficking. ${ }^{350}$ After the decriminalization of prostitution, HTIC judges could be trained to determine whether a person being prosecuted for promoting prostitution has also been exploited, and to what extent. They would then determine the appropriate sentence or remedial measure, which could include education about the harms of the sex trade, individual therapy, and restitution for survivors.

\footnotetext{
${ }^{348}$ See supra notes $276-284$ and accompanying text.

349 Press Release, DeCRIM NY, supra note 16; see also Raven, supra note 7 (stating that the objective of rewriting the statutes on promoting prostitution is to allow sex workers to work together or share a space for safety).

${ }^{350}$ See Human Trafficking Resource Guide, NAT'L CTR. FOR STATE CTS., https://www.ncsc.org/Topics/Alternative-Dockets/Problem-Solving-Courts/Human-Trafficking/ResourceGuide.aspx [https://perma.cc/M2F4-DTLB] (last visited Feb. 7, 2020).
} 


\section{B. Centering the Needs of Survivors Through Reparative Justice and Social Services}

\section{Demanding Restitution from Prostitution Exploiters}

Firstly, New York law should require that prostitution buyers and pimps repair the harm they caused people in prostitution by making their victims whole. ${ }^{351}$ According to the Exited Prostitution Survivor Policy Platform, funding survivor services through increased fines for buyers is one way of achieving reparative justice. ${ }^{352}$ In addition, requiring that pimps and traffickers pay restitution to the people they exploited in prostitution would also provide some reparation for the harm they caused. Once prostitution buying and pimping are recognized as crimes committed against people in prostitution, survivors will be able to seek restitution from buyers and pimps through the New York Penal Law's provision on restitution and reparation. ${ }^{353}$ The legislature could also consider requiring restitution from people convicted of prostitution-related offenses regardless of whether a particular victim is seeking restitution, as the Trafficking Victims Protection Act does for people convicted of trafficking in federal court. ${ }^{354}$

In order to avoid over-criminalizing the poor and to effectively deter wealthy defendants, the legislature could consider implementing sliding scale fines ${ }^{355}$ that take into account each defendant's means. ${ }^{356}$ The fines could be placed in a general victims' fund, which could then be redistributed as restitution to individual victims based on the extent of harm and exploitation that they suffered. The fines could also be used to fund services for people in prostitution.

\footnotetext{
${ }^{351}$ See Hatcher et al., supra note 12, at 4.

${ }^{352} \mathrm{Id}$.

${ }^{353}$ See N.Y. Penal Law $\S 60.27$ (McKinney 2019). Survivors will also be able to seek damages in civil court. $I d$. $\S 60.27 .6$. Addressing prostitution exploitation through civil court litigation is beyond the scope of this Note.

${ }^{354} 18$ U.S.C. $§ 1593$ (2018).

${ }^{355}$ See supra note 127 and accompanying text (explaining the use of sliding scale fines in Sweden).

${ }^{356}$ See Alec Schierenbeck, The Constitutionality of Income-Based Fines, 85 U. CHI. L. REv. 1869, 1871

(2018) (arguing that income-based fines ensure proportionality in sentencing and improve the effectiveness of fines, allowing them to serve as alternatives to incarceration).
} 


\section{Providing Social Services for Survivors and People in Prostitution}

In addition to implementing reparative justice remedies with regards to prostitution exploiters, New York should center the needs of survivors and people in prostitution by funding dedicated social and medical services. According to the Red Umbrella Project, lack of access to employment, stable housing, and healthcare is the greatest issue faced by those in prostitution. ${ }^{357}$ The Gottfried-Salazar bill does not provide for the creation of any services that would help people in prostitution access such resources. ${ }^{358}$ Further, the bill does not address how the state should support outreach efforts once it is no longer able to offer services through the HTICs. ${ }^{359}$

Before amending its prostitution laws, the legislature should identify the needs of survivors and people in prostitution throughout New York State. A legislative committee could be formed to produce a report based on detailed empirical research. ${ }^{360}$ New York should then fund extensive services to address the needs that were identified. These might include direct legal services, physical and mental health care, and access to gainful employment, housing, and benefits. The government should fund various centers across the state, similar to Sweden's prostitution units, ${ }^{361}$ to ensure that survivors and people in prostitution throughout New York have access to these services. The professionals working at these facilities should be trained in trauma-informed care and understand the particular issues that affect prostituted people, such as difficulties trusting people, poverty, addiction, and a history of exploitation. ${ }^{362}$ These services should be accessible to

\footnotetext{
${ }^{357}$ Herrmann, supra note 23, at 99.

${ }^{358}$ See S. S3075, 2020-2021 Sess. (N.Y. 2020).

${ }^{359}$ See supra notes $151-156$.
}

${ }^{360}$ Other countries have based their prostitution laws on empirical research conducted by the legislature. See supra note 120; GEOFFROY, supra note 120, at 16 (stating that France's report on prostitution was produced by a parliamentary committee).

${ }^{361}$ See supra note 125 and accompanying text.

${ }^{362}$ See, e.g., Mathieson et al., supra note 25, at 405 (stating that the employees of the Swedish prostitution units adopt a therapeutic approach, which includes a lot of patience to let relationships with clients develop, and a lack of judgment or criticism of their clients). The EMPOWER clinic is a good example of the types of trauma-informed health services that should be available for people who have been in prostitution. THE EMPOWER CLINIC, https://www.empowergyn.org/the-empower-clinic [https://perma.cc/8VDY-KLCK] (last visited Feb. 12, 2020) (stating that the clinic provides trauma-sensitive, long-term medical care for survivors of sex trafficking and sexual violence, including gynecological and psychological services). 
all people in prostitution, regardless of whether they are looking to exit the sex trade or not.

Because many people are coerced into prostitution by traffickers or structural inequalities ${ }^{363}$ the state should facilitate exit from prostitution. People exiting prostitution require stable housing, ${ }^{364}$ and many must escape an abusive situation. ${ }^{365}$ New York should therefore provide access to housing during the transition period out of prostitution, including specialized safe houses. The state could also offer a monthly stipend to help support those exiting prostitution. ${ }^{366}$ Survivors should have access to long-term services. Exiting prostitution is a long process, ${ }^{367}$ and many survivors continue to suffer harm for years. $^{368}$

One critique of the Equality Model is that it does not provide an adequate legal framework for people who wish to remain in prostitution. ${ }^{369}$ In enacting the Equality Model, New York should therefore ensure that people in prostitution can declare their

\footnotetext{
${ }^{363}$ See supra notes 31-33; see also Nelson Butler, supra note 36, at 95 (arguing that intersecting structural inequalities obscure choice for women of color in prostitution).

${ }^{364}$ Herrmann, supra note 23, at 99.

${ }^{365}$ See, e.g., Gruber et al., supra note 154, at 1357-58 (describing the story of a young woman who was ordered to be detained indefinitely at Rikers Island by an HTIC judge seeking to protect her from an abusive partner who was also her trafficker).
}

${ }^{366}$ See, e.g., Law 2016-444 of April 13, 2016, art. 5 (Fr.) (mandating the creation of a stipend for people exiting prostitution through a special "exit path").

${ }^{367}$ Mathieson et al., supra note 25, at 405 (stating that because exiting prostitution is a process that can take many years, the employees of the Swedish prostitution units do not expect anyone to leave prostitution immediately).

${ }^{368}$ See, e.g., Bridget Perrier, Testimonials, SPACE INT'L, https://www.spaceintl.org/about/testimonials/ [https://perma.cc/S4ZZ-2LLM] (last visited Jan. 26, 2020) (recounting that, after being enslaved in prostitution for ten years, the author cannot get pregnant due to damage to her cervix, still has nightmares, and suffers deep trauma).

${ }^{369}$ See, e.g., FrEEDOM NETwORK USA 2 (2018), https://freedomnetworkusa.org/app/uploads/2018/07/EndDemand.pdf [https://perma.cc/483W-RXEF] (advocating for an increase in the legal rights and protections of people in prostitution and implying that by driving the sex trade underground, partial decriminalization fails to provide adequate protections); see also Press Release, DECRIM NY, supra note 16 (implying that full decriminalization is the best way to provide adequate labor protections for people in prostitution). 
earnings, pay taxes, and receive benefits as independent workers, as is the case in France. $^{370}$

While the legislature should address prostitution exploitation by focusing on the needs of survivors, it should also aim to dismantle the system of prostitution by addressing its root causes.

\section{Addressing the Root Causes of the System of Prostitution}

\section{Educating Our Communities}

The belief that it is humanly and socially acceptable to use one's economic resources to obtain sexual access to another person stems from systemic inequalities. ${ }^{371} \mathrm{In}$ implementing the Equality Model, the New York legislature should allocate resources to educate the state as a whole regarding these issues, particularly targeting efforts to educate students at schools and universities.

Similarly to French law, ${ }^{372}$ New York law could include a provision requiring schools to educate students about the inherent harms of the system of prostitution, the effects that it has on the physical and mental health of those who are prostituted, and the various factors that push people into prostitution. Existing sex education and gender equality classes could include information about prostitution. Education about the issues regarding the sex trade, starting at a young age, has the potential to effect normative change throughout society.

The state should make a special effort to deliver information regarding prostitution exploitation to populations that are at a high risk of containing potential prostitution

\footnotetext{
${ }^{370}$ See supra notes 136-29 and accompanying text.

${ }^{371}$ See Carter \& Giobbe, supra note 59, at 51; see also Hatcher et al., supra note 12, at 5 (stating that " [t] $]$ he buying of sex embodies the power imbalance inherent to the sex trade, which . . . is a profound violation of human rights").

${ }^{372}$ See supra note 133 and accompanying text.
} 
buyers, such as the military, ${ }^{373}$ the police force, ${ }^{374}$ and all-boys schools. ${ }^{375}$ Before being deployed, military personnel should be trained not to sexually exploit people in prostitution abroad. Ideally, these trainings would include testimony from a survivor, to help participants understand the harm.

\section{Addressing the Root Causes of Prostitution}

While the Equality Model is the best legislative solution for combatting prostitution exploitation under our current system, the root causes and structural inequalities that coerce people into prostitution ${ }^{376}$ must be addressed in order to dismantle the system of prostitution. The combination of various factors, such as childhood abuse, involvement in the foster care system, and homelessness, push people into prostitution. ${ }^{377}$ Lack of work authorization makes many immigrant women particularly vulnerable to prostitution and sex trafficking. ${ }^{378}$ Poverty and structural inequalities are perhaps the primary root causes of the system of prostitution. ${ }^{379}$

\footnotetext{
${ }^{373}$ See Dan Lamothe, The U.S. Military's Long, Uncomfortable History with Prostitution Gets New Attention, WASH. Post (Oct. 31, 2014), https://www.washingtonpost.com/news/checkpoint/wp/2014/10/31/the-u-smilitarys-long-uncomfortable-history-with-prostitution-gets-new-attention/ [https://perma.cc/YKD8-2HJ8].

${ }^{374}$ See Sirin Kale, Police Are Allegedly Sleeping with Sex Workers Before Arresting Them, VICE (May 3, 2017), https://www.vice.com/en_us/article/59mbkx/police-are-allegedly-sleeping-with-sex-workers-beforearresting-them [https://perma.cc/S5KB-DEEV].

${ }^{375}$ All-boys schools tend to be more sexist environments than other schools; however, some of them are beginning to talk about gender issues such as sexual harassment and the gender pay gap. Katie Reilly, What Is the Role of an All-Boys School in 2019? How the Elite Institutions Are Trying to Adapt, TIME (Oct. 14, 2019), https://time.com/5687978/all-boys-schools-me-too-movement/ [https://perma.cc/NUD3-Y2Z2].
}

${ }^{376}$ See supra notes 33, 36 and accompanying text.

${ }^{377}$ See supra notes 32-34 and accompanying text; RAPHAEL ET AL., supra note 313, at 49 (finding that running away from home, or homelessness, and early childhood sexual assault create the conditions for prostitution entry); GRAGG ET AL., supra note 313, at 31 (finding that $75 \%$ of the commercially sexually exploited youth identified in New York City and $49 \%$ of those identified in seven upstate counties had experienced placement in foster care).

${ }^{378}$ In the United States, most victims of trafficking are immigrant women. Human Trafficking: Modern Enslavement of Immigrant Women in the United States, ACLU, https://www.aclu.org/other/humantrafficking-modern-enslavement-immigrant-women-united-states [https://perma.cc/VP2X-AM42].

${ }^{379}$ See supra notes 33, 36, 287 and accompanying text. 
As a society, we must therefore improve our means of combating child abuse and transform our punitive approach to child welfare that "regulat[es] and destroy[s] black, brown and indigenous families" by placing children in foster care. ${ }^{380}$ New York should invest in stable housing and services for homeless and runaway youth, including support services and gender-affirming services for LGBTQ+ youth. ${ }^{381}$ While states cannot transform federal immigration policy, New York could support immigration services for survivors of gender-based violence experiencing homelessness, in order to address their need for immigration status before they are preyed upon by traffickers. ${ }^{382}$ Finally, the legislature should address poverty and economic inequalities by guaranteeing a living wage and creating a viable social safety net.

\section{Addressing the Root Causes of Pimping and Trafficking}

Rather than seeking to decriminalize organized commercial sexual exploitation, the New York legislature should explore ways to address the root causes that lead people to exploit others in prostitution through pimping and trafficking. Many pimps and traffickers who are prosecuted come from disadvantaged backgrounds ${ }^{383}$ and are

\footnotetext{
${ }^{380}$ Dorothy Roberts, Abolishing Policing Also Means Abolishing Family Regulation, IMPRINT (June 16, 2020), https://imprintnews.org/child-welfare-2/abolishing-policing-also-means-abolishing-familyregulation/44480. [https://perma.cc/VM6S-FMFJ].

${ }^{381}$ BigeLSEN \& VuOTTO, supra note 313, at 19-21 (advocating for access to shelter, job training, education, and services for every homeless youth as a means of reducing commercial sexual exploitation, and for an increase in support services for LGBTQ+ youth, particularly employment opportunities for transgender youth).

${ }^{382}$ Trafficking survivors can apply for T-nonimmigrant status. Victims of Human Trafficking: T Nonimmigrant Status, U.S. CITIZENSHIP AND IMMIGR. SERVS., https://www.uscis.gov/humanitarian/victimshuman-trafficking-other-crimes/victims-human-trafficking-t-nonimmigrant-status/victims-human-traffickingt-nonimmigrant-status [https://perma.cc/B5ZH-PVSN]. However, this remedy does not apply to people in prostitution who do not qualify as victims of trafficking, and it not address lack of work authorization as a root cause of trafficking.

${ }^{383}$ In a Chicago study with twenty-five ex-pimps, $61 \%$ of the men and $71 \%$ of the women interviewed did not have a high school degree, and $24 \%$ had been in foster care. JoDy RAPHAEL \& BRENDA MYERS-POWELL, DePaul Univ. Coll. of L., From Victims to Victimizers: Interviews with 25 Ex-Pimps in Chicago 1 (2010). In a similar Oregon study, $61 \%$ of the interviewees were high school dropouts, and $41 \%$ were removed from their parents' home when they were children. Katherine Gotch, Preliminary Data on a Sample of Perpetrators of Domestic Trafficking for Sexual Exploitation: Suggestions for Research and Practice, $2 \mathrm{~J}$. Hum. TRAFFICKING 99, 104 (2016).
} 
themselves survivors of abuse. ${ }^{384}$ In fact, the quasi-totality of female pimps, and many male pimps, were exploited in prostitution before becoming traffickers themselves. ${ }^{385}$ Therefore, the same transformative solutions used to address the root causes and structural inequalities that coerce people into prostitution are likely to decrease the number of people who exploit others through pimping and trafficking.

The full decriminalization of the sex trade that the Gottfried-Salazar bill proposes would only entrench an age-old system of oppression that relies on structural inequalities and the commodification of women's bodies for men's financial benefit and sexual pleasure. ${ }^{386}$ New York State should recognize that prostitution is a system of oppression and aim to dismantle it by addressing the needs of its survivors and targeting its root causes.

\section{CONCLUSION}

Many left-leaning politicians support the full decriminalization of the sex trade, which they view as a progressive solution. ${ }^{387}$ New York's Gottfried-Salazar bill illustrates an attempt to legitimize prostitution as work and to improve the conditions of prostitution by making all aspects of the sex trade legal. The experiences of other countries, however, indicate that full decriminalization is not a viable solution to the exploitation of people in prostitution. Instead of legitimizing the sex trade, a truly progressive solution should aim to dismantle the system of prostitution. Legislators and politicians across the country seeking to address sexual exploitation must center the needs

\footnotetext{
${ }^{384}$ In the Chicago study, $88 \%$ of participants experienced physical abuse as children, $76 \%$ experienced childhood sexual assault, and $48 \%$ ran away from home due to physical or sexual abuse. RAPHAEL \& MYERSPowelL, supra note 383 , at 1 . In the Oregon study, $18.5 \%$ of participants were victims of physical abuse as children, and 26\% experienced childhood sexual abuse. Gotch, supra note 383, at 104.

${ }^{385}$ RAPHAEL \& Myers-Powell, supra note 383 , at 1 (100\% of female participants and $56 \%$ of male participants sold sex prior to pimping.).

${ }^{386}$ See supra note 209 and accompanying text.

387 Tiffany Cabán, arguably the most progressive candidate in the last election for Queens district attorney, supported full decriminalization. Otillia Steadman, Sex Work Could Soon Be Allowed in a Huge Part of New York City, BuzzFEED (June 14, 2019), https://www.buzzfeednews.com/article/otilliasteadman/tiffany-cabansex-work-queens-decriminalization-new-york [https://perma.cc/JD5J-2SYH]. Former Democratic candidates for the 2020 presidential election Bernie Sanders and Elizabeth Warren have both stated that they were "open to decriminalization." Aris Folley, Bernie Sanders Open to Decriminalizing Sex Work, THE HiLl (June 20, 2019), https://thehill.com/homenews/campaign/449558-bernie-sanders-says-hed-consider-sex-workdecriminalization [https://perma.cc/P43F-VBB7].
} 
of survivors and people in prostitution by adopting the Equality Model and addressing the root causes of prostitution exploitation. 